\title{
APS Distinguished Service Award
}

This award honors APS members who have provided sustained, outstanding leadership to the society, while also furthering the science of plant pathology. This award is only presented upon the recommendation of APS Council. doi:10.1094/PHYTO99-1-0019

\section{James D. MacDonald}

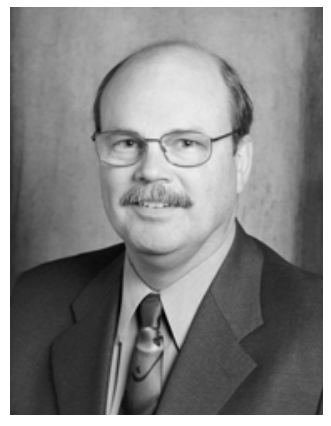

James D. MacDonald was born in Portland, OR, in 1948. Growing up in a career Navy family, he lived in many different places around the world before his family settled in California, where he attended and graduated from high school. He received his B.S. (1973), M.S. (1976), and Ph.D. (1977) degrees, all in plant pathology, from the University of California (UC), Davis. He was appointed to the faculty at UC Davis in 1978, holding joint appointments in the Departments of Plant Pathology and Environmental Horticulture. He rose through the professorial ranks, served as department chair of plant pathology from 1995 to 1999 and, since 1999, has served as executive associate dean of the College of Agricultural and Environmental Sciences (CAES) at Davis. MacDonald has assumed a number of important leadership roles in service to UC and to APS, including president of our society in 2004.

MacDonald has sustained an extraordinarily high level of productivity in university and public service and professional activity. His activities with APS are particularly noteworthy. He has been very active in our society throughout his career, and his contributions are multifaceted, extensive, and substantive. He was a member of the Committee on Diseases of Ornamentals and Turfgrasses (1986-1989), secretary-treasurer of the Pacific Division (1988-1990), and an associate editor for Plant Disease (1991-1993). He served as the assigning editor (1993-1997) for Plant Disease Notes and as senior editor for APS PRESS from 1994 to 1997. At the time, he was a strong proponent of and provided creative leadership for our society's initiatives in electronic communication technologies. He developed processes for fully electronic submission, review, and publication of Plant Disease Notes. Because of his progressive and innovative leadership in this area, he was appointed (in 1995) as the first chair of the APS Electronic Technology Advisory Committee. In 1997, he was appointed as the first director of the APS Office of Electronic Communications, serving in this capacity until 2002. He was responsible for working with the APS leadership and the Publications Board to make all the society's journals available online, for redesigning the society's website (APSnet), for conceiving and organizing the launch of the all-electronic journal Plant Health Progress and the APSnet Education Center, for fostering the development of the Plant Management Network (which now houses four electronic journals), and for dealing with many policy and legal issues related to electronic publications. Related to his work with electronic communications have been his endeavors to adopt new technologies to improve the learning experience for students. In 1997, he coauthored with Gail Schumann a CD-Rom entitled Turfgrass Diseases: Diagnosis and Management through APS PRESS. As an application of computer technologies to present educational materials, this CD earned the 1998 Media Award of Excellence from The National Association of Colleges and Teachers of Agriculture. Also in 1998, he received the APS
Excellence in Teaching Award and the Distinguished Service Award-Outstanding Faculty presented by the UC Division of Agriculture and Natural Resources (DANR). These awards recognize his effectiveness in teaching, his creative use of advanced teaching technology, and his extraordinary efforts in research outreach.

His service to APS continued with his election as vice president in August 2002, leading ultimately to his leadership as president from August 2004 through the annual meeting in Austin, TX, in 2005. MacDonald's election to the highest office in our professional society is a testament to the esteem and high regard in which he is held by his colleagues across the country and to his ongoing creative leadership in society policy and procedures. Throughout this period, he has been active in APS Council matters and special initiatives and projects. He is a visionary leader for APS, consistently suggesting innovations that will keep APS relevant to its members and society for decades to come. A member of the APS Public Policy Board (PPB) since 2003, he has been particularly active in the society's interactions with federal agencies and national and state policy makers. For example, he has represented APS on initiatives in plant biosecurity, including leadership and liaison with the National Plant Disease Recovery System. This ongoing program is implementing plans to address high-consequence plant disease agents and involves federal and state agencies and land-grant universities. He currently chairs an ad hoc APS committee charged to assess existing capabilities and future needs in plant pathology education. Understanding that a meaningful initiative must be based on evidence, he began with surveys of the expected future needs for plant pathologists within academia, industry, and government and of the opinions of current plant pathology students. The survey results, which he presented to APS members at the national meeting in San Diego, CA, will be the focus, in 2008, of a national workshop to develop new strategies for meeting those needs. Through his efforts on the APS $\mathrm{PPB}$, MacDonald has proved very effective at promoting the relevance of plant pathology and plant pathologists.

In addition to MacDonald's leadership and extensive service to APS, it is important to recognize his duties as executive associate dean of CAES at Davis. This is the number two executive position in the college, and it carries a varied and demanding administrative workload with overall responsibility for day-to-day operations of the college. His responsibilities are in five major areas: resource planning and budget, academic personnel management, staff personnel management, $\mathrm{CE}$ and Agricultural Experiment Station (AES) administration, and other administrative duties and functions. He handles these duties superbly. He was instrumental in enabling the college to weather the challenges of the unprecedented and severe budget cuts in 2001-2003. This required extraordinary efforts and careful planning to adjust to the new order without devastating the college. He deserves a lot of credit for his participation in the conception and implementation of the various aspects of the plan. MacDonald is also an excellent representative of the college to the statewide DANR and in other committees of importance to AES. He has been especially active in promoting AES as a separate organizational entity with a clear mission, an effort to add greater definition and distinction to the responsibilities inherent in AES appointments. During his tenure, there 
have been many positive programmatic changes and new opportunities for CAES, including the Mondavi Institute, new facilities and renovations of old ones, and going forward with certain strategic initiatives in the college academic plan. In all of these, he has played a key role, and, in some, the key role, in planning or implementation. Space does not permit a full accounting of MacDonald's substantial contributions to the college, campus, and the statewide DANR.

\section{APS Fellows}

The Society grants this honor to a current APS member in recognition of distinguished contributions to plant pathology or to The American Phytopathological Society.

\section{John Herrick Andrews}

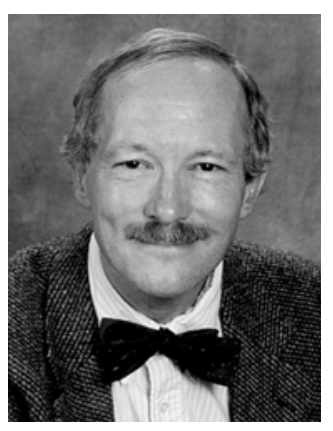

John Herrick Andrews was born in Montréal and raised in rural southern Québec, Canada. Encouraged by a high school science teacher, he enrolled at MacDonald College of McGill University and earned a B.Sc. (Agr.) degree in 1967. As an undergraduate, he took an introductory course in plant pathology taught by W. E. Sackston and became fascinated with diseases of plants. Aspirations to save the magnificent American elm led him to the University of Maine to do M.S. research on Dutch elm disease with R. J. Campana and R. C. McCrum. He then went west to study plant virology with Thomas Shalla at the University of CaliforniaDavis and received awards for his 1973 Ph.D. cytological study of pinwheel inclusions induced by Tobacco etch virus. He subsequently obtained a postdoctoral fellowship to do research with David Ingram at Cambridge University on the downy mildew infection process. Returning to Canada as a postdoc in the Botany Department at the University of British Columbia, he pursued his fascination with diseases of seaweeds, an idea that had been in his mind since taking a course in marine phycology at Maine years earlier. In that era, essentially nothing was known of aquatic pathology, and Andrews was probably the only plant pathologist in the world who donned scuba gear to do his field work!

In 1976, Andrews joined the faculty in the Department of Plant Pathology at the University of Wisconsin-Madison, where he developed two concurrent research programs. One continued his interest in plant disease in oceans and lakes and focused on the pathology of the submerged aquatic weed Eurasian watermilfoil; the other was on the microbial ecology of the phyllosphere. Andrews published 13 papers and reviews on disease in aquatic systems, but it was his groundbreaking work on fungal ecology and the microbial ecology of the phyllosphere that changed the way we view fungi as organisms and the leaf surface and its inhabitants. The microbial ecology phase of his program is documented in 82 publications. He views microbial ecology through the lens of plant and animal ecology and his 1991 Springer textbook, Comparative Ecology of Microorganisms and Macroorganisms, remains unique in the field. A second edition is in progress.

When Andrews launched his career, most work on the "ecology" of fungi on leaves was purely descriptive. He was a pioneer among plant pathologists in applying ecological theory and quantitative approaches to understand the processes of immigration, emigration, multiplication, and death that influence the size of epiphytic microbial populations. With his colleagues R. F. Harris and D. I. Rouse, Andrews gave the famous theory of $r$ - and $K$-selection (developed originally for macroorganisms), a mechanistic and microbial perspective. In collaboration with his doc- toral student L. L. Kinkel and statistician E. V. Nordheim, Andrews showed that fungal species dynamics on leaves follow much the same pattern as do immigration and extinction events of plant and animal species on oceanic islands (theory of island biogeography). With mathematician Tony Ives and others, he used concepts of metapopulation biology to explain the roles of dispersal and density dependence on microbial population dynamics on leaf islands. More recently, he has visualized bacteria and fungi as being modular in design and biology, analogous to sessile clonal organisms, such as benthic invertebrates. To understand the basic principles of how communities form, he and Harris are now studying the assembly of primordial communities of progenotes, representing the inception of all of ecology. These and other insights have stimulated the thinking and research of plant pathologists and have attracted the attention of the larger scientific community to plant pathology.

Many of Andrews' fundamental advances in microbial ecology came about because of a much more applied charge he was given upon arriving at Madison: to develop a teaching and research program in integrated pest management. Andrews chose the economically important disease apple scab as a model system. His group's work in the late 1970s and 1980s on fungal antagonists of Venturia inaequalis resulted in numerous publications, still cited today, and a patent on the use of antagonists for biological control.

Over the past 15 years, the Andrews laboratory has been a leader in advanced microscopy and image analysis, such as fluorescence in situ hybridization, to visualize the fungal colonization process under natural conditions. Their work on Aureobasidium pullalans, a predominant yeastlike inhabitant of apple leaves, indicates not only that the leaf habitat is highly variable but that plants may facilitate epiphytic colonization along preferential routes, such as veinal pathways. These findings provide interesting basic insight on how microbes colonize a heterogeneous landscape and on important ramifications for biological control, where success depends on the relative locations of pathogens and antagonists on the phylloplane.

In addition to his internationally recognized research, Andrews has played a major teaching role in nine courses, several of which he created. These range from pest management, to ethics, to environmental law. This is a testament to his breadth of knowledge and dedication to educating future scientists, inside and outside of plant pathology. His creative approach to diverse scientific topics has led to frequent speaking invitations in the United States and 10 other countries.

Andrews has been committed to service for his university and profession. He has served on numerous influential committees at the University of Wisconsin. From 1998 to 2004, he was chair of the Department of Plant Pathology and currently is the director of the Officer Education Program. Off-campus, he has served on numerous grant review panels and editorial boards. In APS, Andrews was a founding member of the Phyllosphere Ecology Committee and has chaired or served as a member of multiple 
other committees. In 2002, he was elected to APS Council and, in 2005-2006, served as APS president, a role he approached with the same level of energy, integrity, and creativity that he has always devoted to research.

For his imaginative research, dedicated teaching that has spanned basic ecology to integrated pest management, extraordinary service to the discipline of plant pathology, and visionary leadership, Andrews is highly deserving of the APS Fellow Award.

\section{Claude M. Fauquet}

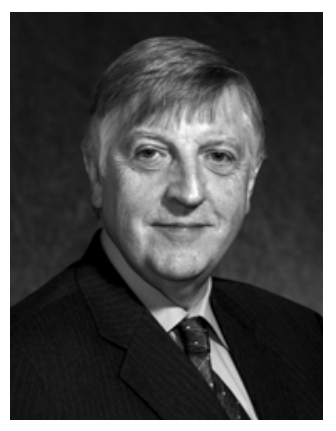

Claude M. Fauquet is director of the International Laboratory for Tropical Agricultural Biotechnology (ILTAB) and member and principal investigator at the Donald Danforth Plant Science Center in St. Louis, MO, since 1999. He is adjunct professor at the University of Missouri-Columbia and at the University of Missouri-St. Louis. He received his Ph.D. degree in biochemistry from the University Louis Pasteur in Strasburg, France, in 1974. Fauquet took a position at ORSTOM (now IRD [Institut de Recherche pour le Développement]), a French public research institute dedicated to helping developing countries, and served as plant virologist in Abidjan, Ivory Coast, West Africa, where he stayed 14 years. While in Africa, Fauquet worked with 45 different viral diseases affecting food crops, vegetables, and industrial crops. In 1983, Fauquet obtained one of the first research grants awarded by the European Community, and he developed an interdisciplinary project on the epidemiology of cassava mosaic disease (CMD). These efforts resulted in a comprehensive epidemiological study of this very important virus disease. At the end of this project, in 1987, Fauquet organized a pan-African meeting on CMD in the Ivory Coast, where it was proposed to develop cassava biotechnology to better control this disease. In 1988, Fauquet undertook a 2-year sabbatical at Washington University with R. N. Beachy. Because of his African experience, he obtained grants from the Rockefeller Foundation and IRD to work on rice and cassava biotechnology.

In 1991, Fauquet cofounded ILTAB at The Scripps Research Institute (TSRI) with Beachy. IRD provided full support for seven scientists. ILTAB focused research on tropical biotechnology for virus diseases of tomato, cassava, and rice. ILTAB scientists were the first to develop a routine rice transformation system and obtained the first transgenic cassava in 1995. More than 17 different viruses were studied and novel control measures using genetic engineering were developed for tomato and rice. In 1996, an international scientific review team concluded that ILTAB's research and training were excellent and recommended continuation of the project.

When Beachy became president of the Danforth Center in 1998, he invited Fauquet to join the institute, where he currently leads ILTAB in research projects concerning cassava genetic transformation for virus resistance and biofortification, promoter studies, gene silencing, and molecular plant virology of geminiviruses. Fauquet was the first to find that geminiviruses encode for at least two gene silencing protein suppressors. Their complementary and combinatorial action is responsible for the synergistic symptoms observed in cassava in Uganda in the 1990s that led to a pandemic disease now spreading westward across Africa. $\mathrm{He}$ also discovered that the mode of action of the AC4 suppressor is unique in that it binds to small miRNAs of the host and consequently induces drastic malformation symptoms. Fauquet is also cofounder and cochair of the Global Cassava Partnership, a network whose goal is to enhance scientific and financial invest- ment in cassava. Notably, he obtained from the U.S. Department of Energy a grant for sequencing the cassava genome.

Fauquet has provided innovative numerical approaches using sequence data for the taxonomy of geminiviruses and potyviruses. $\mathrm{He}$ is the world leader in developing the modern classification system for geminiviruses and their satellites. As part of these studies, he was the first to recognize the importance of interspecies recombination in the evolution of geminiviruses. He was secretary of the International Committee on the Taxonomy of Viruses (ICTV) for 18 years and continues his involvement in the classification of viruses through the creation of the International Virus Database Network. Fauquet has published more than 179 papers in scientific peer-reviewed journals and organized many scientific meetings. He has edited and coedited several books, including four ICTV Reports that are the definitive works on virus taxonomy, and two editions of the Encyclopedia of Virology and has participated in more than 200 meetings, symposia, and congresses. He is a fellow of the American Association for the Advancement of Science and a member of the St. Louis Academy of Sciences and, in 2007, was knighted "Chevalier de l'Ordre des Palmes Académiques" by the French Minister of Higher Education and Research.

\section{Deborah R. Fravel}

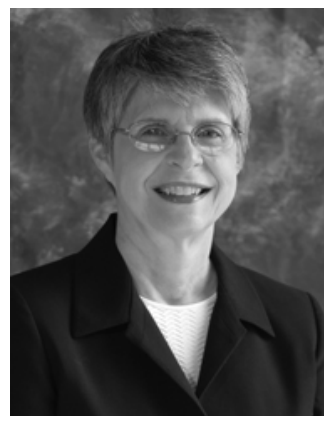

Deborah R. Fravel was born in Morgantown, WV, received her B.A. degree in botany at Duke University in 1972, and her M.S. and Ph.D. degrees in plant pathology at North Carolina State University in Raleigh. Fravel joined the USDA Agricultural Research Service (ARS) at Beltsville, MD, in 1982 as a postdoctoral research associate and accepted a position as a research plant pathologist with the Soilborne Diseases Laboratory in 1984. She has served in several leadership positions within ARS, as acting national program leader for horticulture and sugar crops in 1999, as acting research leader of the Biological Control of Plant Diseases Laboratory from 1999 to 2000, and in her current position as research leader of the Genetic Improvement of Fruit and Vegetables Laboratory. Fravel is recognized internationally as a leader in research on the biological control of plant diseases and has made numerous landmark discoveries in this field.

Early in her career, Fravel discovered that the soilborne fungus Talaromyces flavus suppressed Verticillium wilt of several crops. Later, she led a research team that unraveled a novel mechanism of disease suppression by T. flavus. This team discovered that glucose oxidase produced by $T$. flavus generates hydrogen peroxide that kills microsclerotia of the soilborne pathogen Verticillium dahliae. This study was the first to identify the indirect action of an enzyme as a mechanism for biological control and laid the groundwork for others who then developed transgenic cotton plants expressing glucose oxidase, which are resistant to Verticillium wilt. Based on this work, Fravel was invited to write an article on antibiosis for the Annual Review of Phytopathology.

Fravel also participated in a research team that developed formulations that have been critical to the advancement of biological control. This team obtained two patents for the development of an alginate-clay matrix as an effective formulation for the biological control of fungi and bacteria. The alginate formulation was key to the development of GlioGard, the first fungus registered by the U.S. Environmental Protection Agency for control of plant diseases. The alginate prill is also widely used to produce consistent inoculum for experimental field trials of biological control agents. She also developed bacterial alginates 
for use in formulations, demonstrating that they were chemically more consistent and cheaper than marine alginates.

Throughout her career, Fravel has recognized that the success of biological control depends on effective biocontrol agents and, just as importantly, on knowledge of the factors that influence their efficacy. Therefore, she has taken a broad approach toward the development of management strategies that employ biological control agents as well as agricultural practices that promote the survival and activity of those agents. This approach has required the development of knowledge of pathogen biology, disease epidemiology, and the mechanisms of biological control. Her development of mathematical models to describe "epidemics" of Sporidesmium sclerotivorum controlling lettuce drop, caused by Sclerotinia minor, highlighted seasonal variation in performance of the biocontrol agent and allowed calculation of the minimum amount of biocontrol agent needed. By maximizing the value of expensive inoculum, Fravel demonstrated that the biocontrol agent could provide economic control of lettuce drop in production fields. Studying another system, Fravel showed that sublethal doses of fumigants or solarization resulted in weakened propagules of Verticillium dahliae that were extremely susceptible to the toxic effects of a biocontrol agent. Her work established that either sublethal heating (solarization) or fumigation with methyl bromide acted additively with $T$. flavus to suppress Verticillium wilt of eggplant. Later, a multipronged approach toward the management of Fusarium wilt led to the identification of a nonpathogenic isolate of Fusarium oxysporum that controls this disease on several crop plants, as well as an effective formulation, and to knowledge of the factors that influence the success of the biocontrol agent in many field environments. The nonpathogenic isolate of $F$. oxysporum has been used successfully in a commercial setting to reduce the number of dead plants by $50 \%$. These projects demonstrate Fravel's ability to translate her basic research into production systems.

Fravel is recognized worldwide as a leader in the field of biological control, particularly in the biological control of fungal wilt pathogens and in the formulation and commercialization of biocontrol agents. She has written numerous invited review articles on these topics, including a recent review of the commercialization of biological control for Annual Review of Phytopathology. She is widely sought out as a speaker at national and international conferences and has served on the scientific program committees for several international symposia on biological control or soilborne pathogens. She has conducted a great deal of collaborative research with scientists in industry and academia, hosting scientists from Russia, Greece, the Philippines, and Venezuela who have conducted research in her laboratory. She has received numerous invitations to visit laboratories in other countries (Russia, Brazil, Australia, New Zealand, Israel, France, Italy, and Greece) to consult on areas of common interest. Over the course of her career, she has served as a mentor to seven postdoctoral research associates.

In addition to a very productive research program, Fravel has an outstanding record of professional service, particularly to The American Phytopathological Society. She served as a senior editor of Phytopathology, responsible for biological control, from 2000 to 2002 and as an associate editor of Phytopathology from 1990 to 1992. She has been an active member of six committees and served as chair of the Biological Control and the Soil Microbiology and Root Diseases Committees. She established and maintained a valuable web site for the Biological Control Committee, listing commercially available products for the biocontrol of plant pathogens. In the early 1990s, she was one of three plant pathologists selected to participate in an APS program supporting the travel of women scientists to plant pathology departments that had no women on the faculty but several women graduate students. She has also served her profession as president of the International Verticillium Society, as a member of the Board of
Directors of the Washington Academy of Sciences, and by contributions to numerous committees of the USDA ARS.

\section{Dean W. Gabriel}

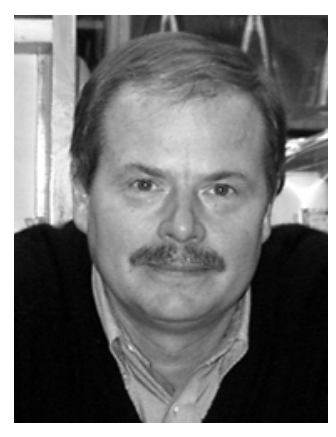

Dean W. Gabriel was born in Washington, DC, received his B.A., M.S., and Ph.D. degrees from Michigan State University, and was involved in some of the earliest research on the molecular basis of gene-for-gene interactions in Al Ellingboe's lab. He subsequently served as research associate at Oregon State University and assistant professor at Oklahoma State University. Gabriel was hired at the University of Florida (UF) in 1984 as a bacterial geneticist and was immediately directed to focus on citrus canker disease. At the time, the state of Florida was engaged in a program to eradicate what it called a "form" of citrus canker. He applied a new technique at the time, RFLP, to demonstrate that the new disease "form" was quite distinct from known citrus canker strains, which he proposed to be reinstated into an entirely separate species, Xanthomonas citri. This research piqued his interest in exotic and emerging pathogens. He anticipated that Florida's increasing population and incursions into agricultural areas would result in the continuous introduction of exotic pathogens into the state, and this triggered his efforts to design and obtain initial funding to build a Biological Safety Level 3 Plant Containment Facility, the first such facility in the state. He has served as scientific director of that facility since its founding in 1987.

In addition to the diagnostic advances made by early research in his lab, he identified and cloned the principal pathogenicity effector gene from $X$. citri that is responsible for eliciting the "canker" phenotype on citrus. His group demonstrated that the causal gene naturally occurred on a self-mobilizing plasmid in some $X$. citri strains and also demonstrated that this gene expressed an elicitor protein with plant nuclear targeting signals that causes most of the observed symptoms of citrus canker. The fact that the gene was on a self-mobilizing plasmid indicated that new citrus canker strains could arise by horizontal gene transfer. He served on the USDA Biotechnology Risk Assessment Panel in 1997 and managed the panel in 1998. In 2002, he set up a joint UF/USDA web site to highlight the science behind biotechnology risk assessment for experts and teachers and has assisted the Interdisciplinary Center for Biotechnology Research (ICBR) program efforts to educate high school teachers about biotechnology and recombinant DNA.

His past 7 years of research and teaching on exotic pathogens have been highly productive. He has been sought as an expert witness and consultant for canker (in Florida, Australia, China, and Oman), citrus greening (Florida), and citrus variegated chlorosis or CVC (Brazil). His activities gained the attention of NASA, and because of his perspective on risk assessment of introduced plant pathogens, he was invited to help with a risk assessment of soil samples that might be returned by spacecraft from Mars and to help develop the Mars return sample biocontainment protocol to be used by NASA. He served from 1998 to 2002 on the Brazilian CVC Functional Genomics Advisory Panel and learned about the first plant-pathogenic bacterial genome ever sequenced. CVC, also a USDA select agent not present in the United States, threatens to be much more serious than canker to the U.S. citrus industry. A similar disease, Pierce's disease, now threatens the California grape industry and is a primary reason why viniferous grapes cannot be grown in Florida. His work on both diseases has resulted in his active participation for the last 5 years in California's Pierce's disease program. 
He anticipated the introduction of citrus greening into the state and his program has been able to quickly respond to this emerging threat to citrus. His lab personnel and the UF Plant Containment Facility were the first in the state to be licensed by USDA to work with this select agent. This has already resulted in the identification of the ornamental plant orange jasmine as a hidden carrier for greening, greatly assisting the state's control response. This has also resulted in funding by USDA-APHIS for a greening genome sequencing project, and his lab is among the first in the world to see greening genomic sequence data. He has assembled an international team of experts to annotate this genome. He has initiated a genomics web site (not yet public) for citrus greening.

He has served on several competitive grant review panels, including USDA National Research Initiative panels. In the past 7 years, he has received more than $\$ 2.9$ million in grants, published 19 refereed articles in top-tier molecular journals, mentored four postdocs, chaired four Ph.D. and three M.S. committees, and served on several student committees. He has six patents that have been awarded or are in the process of application at this time. He has had two of his patent applications licensed from the UF Office of Technology Licensing and a third is in negotiations for licensing at this time. He is founder and president of a private company, Integrated Plant Genetics, Inc., that has licensed two UF technologies and is a client company at the UF Sid Martin Biotechnology Development Institute (BDI) in Alachua (www.ipgenetics.com).

He has been an important member of the plant pathology community and of his department. A hallmark of his research has been the practical impact of his molecular and basic research program. He participates in teaching Molecular Plant Pathology and has assisted in the reorganization of the department's molecular biology classes, an important part of the curriculum. He has team-taught the foundational plant molecular and cellular biology class, Advanced Molecular Genetics, which has received solid reviews. The students especially appreciate his private industry perspective on the applications of genetic engineering in plants.

\section{David M. Gadoury}

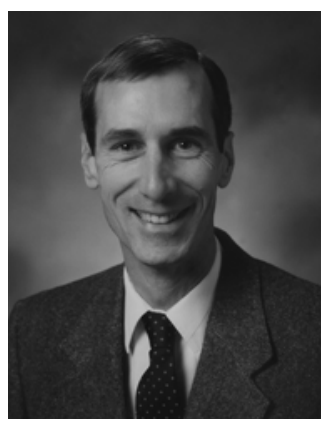

David M. Gadoury's research has had an immense impact on the management of fruit diseases over the past 25 years and his studies have profoundly influenced integrated pest management (IPM) practices on apples and grapes worldwide. Much of his research has focused on two of the most devastating and extensively studied diseases of fruit crops: apple scab and grape powdery mildew. In each case, his findings have substantially revised long-held views. A major goal of his research has been to clarify how pathogens survive the intercrop period and then become reestablished in the crop. Gadoury thus chose a less-traveled path, since many labs study disease increase but few investigate what sets the stage for an epidemic.

His impact on the epidemiology and management of apple scab has been profound. Prior to his work, there was no practical way to relate inoculum dose to disease management practices. As an M.S. and Ph.D. student with William MacHardy at the University of New Hampshire, and later at Cornell University, Gadoury pioneered the potential ascospore dose (PAD) concept and conducted the field and lab studies to define an action threshold that growers could use to time initiation of a springtime fungicide spray program. This action threshold improved the efficiency of fungicide spraying and provided growers with a way to integrate sanitation practices for overwintering leaves in order to minimize fungicide needs. The PAD action threshold and the model to estimate ascospore maturity have since been incorporated into apple scab IPM programs worldwide.

Gadoury's contribution to scab epidemiology extends well beyond the PAD concept, however. His collaborative studies with colleagues in the United States and Norway included (i) impact of the environment (dew, light, and relative humidity) on the discharge and dissemination of ascospores, which led to a major revision of the traditional Mills Table for assessing scab risk; (ii) elucidation of the influence of temperature on the development of pseudothecia, asci, and ascospores, culminating in a degree-day model supplementing the PAD approach; (iii) preparation and interpretation of pseudothecial assessment methods to trace ascospore maturation and release; and (iv) clarification of variation and reduction of sources of error in squash mounts. Few scientists have had a more diverse and far-reaching impact on the study and management of apple scab.

Gadoury's collaboration with Roger Pearson at Cornell overturned a century of dogma concerning the role of cleistothecia in grape powdery mildew. Cleistothecia were previously believed to be degenerate structures that were nonfunctional because few viable structures were found on leaves and inoculum from these structures failed to reproduce the disease. Gadoury and Pearson discovered that the cleistothecia were passively dispersed by latesummer rains from the site of formation on leaves to crevices within the bark of the vine. This insight forced a complete reassessment of the role of cleistothecia in the disease cycle and explained why disease management programs that focused on other putative sources of inoculum often provided mediocre control. The model of passive dispersal of cleistothecia to secondary substrates has since been demonstrated in several other pathosystems. Gadoury and Pearson received the Lee M. Hutchins Award of APS in recognition of this innovative work.

Equally important was Gadoury's role with others at Cornell in establishing the critical function of early-season control of grape powdery mildew. In a series of elegant lab and vineyard studies lead by Gadoury, they showed convincingly that ontogenic resistance limits susceptibility of grape berries to a 4-week period around bloom, disproving the long-held view that berries remained susceptible for 2 months. The outcome of this breakthrough was a significant adjustment and reduction of fungicide spray schedules worldwide. By precisely identifying the end of the susceptibility period, Gadoury and colleagues also helped wine-grape growers avoid premature termination of spraying that contributed to an insidious form of the disease called "diffuse powdery mildew," which predisposes grapes to contamination by spoilage microorganisms that create off-flavors in wine.

The impact of Gadoury's work in fruit pathology is affirmed by 66 refereed research publications, nearly 800 citations of his papers (an extraordinary number in fruit pathology), numerous visiting research and lecture experiences around the world, and service on review panels. Comments by colleagues on his impact were uniformly glowing. A prominent colleague states that "he is THE authority worldwide on apple scab and grape powdery mildew." Colleagues consistently stated that "his papers should be required reading for all grad students in plant pathology... because of their logical and systematic approach and painstaking attention to detail." Gadoury was also praised for "the amazing breadth of his approach to solving problems, ranging from mycology to epidemiology, genetics, biophysics, and molecular host-pathogen interactions."

Gadoury is an enthusiastic and committed citizen of his department and of APS. He is seen as a "brilliant mentor for graduate students" whose "natural and infectious curiosity challenges his students" and has created a "legacy of students with successful careers in plant pathology." He has lectured internationally on writing effectively for diverse competitive grants programs and 
on the process of preparing articles for refereed journals. He has advocated forcefully and effectively, both at Cornell and through APS committees, for a greater emphasis on undergraduate teaching and work experience in order to recruit future plant pathologists, and he now chairs a committee tasked with identifying future challenges to the profession of plant pathology.

For his innovative contributions to fruit epidemiology, highly effective mentoring of young scientists, and exemplary service, Gadoury is truly worthy of receiving the APS Fellow Award.

A native of Rhode Island, Gadoury received his B.S. degree from the University of Rhode Island in 1978. His M.S. and Ph.D. degrees in plant pathology were earned at University of New Hampshire in 1981 and 1984, respectively. At the New York State Experiment Station in Geneva, he was hired in 1985 as a research associate II, rising to research associate III in 1990 and to senior research associate in 1993. Gadoury is an avid hiker and skier and is completing a second round of ascents of all 48 high peaks in the White Mountains of New Hampshire.

\section{Stephen B. Goodwin}

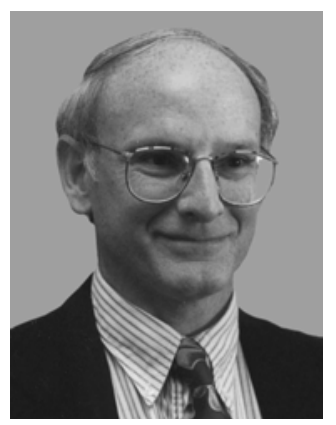

Stephen B. Goodwin was born in Bethlehem, PA, but grew up mostly in Williamsburg, VA. He received his B.S. degree in botany from Duke University in 1981 and his Ph.D. degree in genetics from the University of California, Davis in 1988. He completed a postdoctoral appointment at Cornell University before accepting his current positions as research plant pathologist with the USDA ARS and as an adjunct faculty member at Purdue University. $\mathrm{He}$ is an internationally recognized authority in the fields of fungal population genetics and evolution and of resistance to Septoria tritici blotch in wheat. The techniques he developed and the discoveries he made contributed significantly to our understanding of host-pathogen interactions and to the improvement of disease resistance in cereals.

Goodwin's research is focused on pathogen genetics, genomics, and population biology and on molecular and classical analyses of genes for resistance to fungal pathogens. During his Ph.D. work, he significantly increased our understanding of the barley scald pathogen, Rhynchosporium secalis. Goodwin concluded that parasexual recombination was not important in $R$. secalis, contrary to earlier reports, and stimulated research into the relevance of sexual reproduction. He developed a comprehensive, standardized nomenclature for pathotypes of $R$. secalis that is now widely used. He used this nomenclature to analyze pathogenicity variation within and among populations of $R$. secalis and to infer the probable resistance genes in barley cultivars. Resistance breeding programs in the Pacific Northwest and Canada changed to emphasize quantitative resistance after his work showed that classical approaches probably would not be successful. More recently, Goodwin used phylogenetic analyses to show that $R$. secalis is closely related to fungi in the sexual genera Tapesia and Pyrenopeziza. This work predicted what the sexual stage of this organism should look like, suggested where it might be found, and guided scientists in other laboratories to clone its mating-type genes.

Goodwin's postdoctoral work in William Fry's lab on the potato late blight pathogen Phytophthora infestans stands in a class by itself. He developed the DNA fingerprint and isozyme identification systems that have been used worldwide to characterize local populations of this devastating pathogen. Goodwin's work showed that the global pandemic of potato late blight was due to a single clone that escaped from Mexico, and he played the leading role in shaping our understanding of the population biology of this pathogen. He showed that sexual populations of $P$. infestans are now emerging as a result of the "escape" of new strains of $P$. infestans from Mexico. Many groups around the world continue to build on his findings. Goodwin took the $P$. infestans work a step further by assessing the genetic relationships among $P$. infestans and its close relatives, determining the likely ancestors that gave rise to the potato-infecting population. This work was very significant as it offered new insights into the origins of plant pathogens, illustrating that host jumps following the movement of crops into new areas of cultivation may be a common mechanism for the emergence of new pathogens.

After joining USDA ARS, Goodwin turned his attention to the wheat pathogen Mycosphaerella graminicola (anamorph Septoria tritici). In collaboration with Gert Kema (Plant Research International, Wageningen, Netherlands), he developed the first genetic map for $M$. graminicola. He developed molecular markers that could be used easily in other laboratories and discovered the first transposon in this fungus. He recently identified 50 polymorphic microsatellite loci and added 23 of these to the existing genetic map. Other labs are using these microsatellites for phylogeographical studies of $M$. graminicola.

Goodwin recently showed that a barley pathogen, Septoria passerinii, is closely related to $S$. tritici. The evolutionary relationships between these fungi were not known previously, but he showed that they had a common ancestor in their recent evolutionary history. He cloned both mating-type genes from $S$. passerinii and showed that this pathogen reproduced sexually, rather than exclusively asexually as believed previously, which changed our understanding of its epidemiology. This work stimulated a search for the sexual stage of $S$. passerinii, leading to its rapid identification as another Mycosphaerella species. An expanded phylogenetic analysis of the genus Mycosphaerella, including other fungi associated with this genus, showed that toxin-producing members of the asexual genus Cercospora evolved only once and that all Cercospora are related to the sexual genus Mycosphaerella. These phylogenetic analyses added significantly to our understanding of the origins and evolution of several important cereal pathogens and cleared up several long-standing questions in fungal taxonomy and systematics. Most recently, Goodwin and others procured the resources to sequence the genomes of $M$. graminicola and $M$. fijiensis, causal agent of black Sigatoka on banana. Comparative analyses of these genomes will likely lead to new insights regarding the genetic basis of host specialization.

Goodwin also made significant contributions in his analysis of resistance to Septoria tritici blotch in wheat. His lab mapped four previously identified sources plus a new gene for resistance to $M$. graminicola. He discovered one or more molecular markers linked to each of the genes for resistance that now can be used by plant breeders to increase the level of resistance in future wheat cultivars. The markers and corresponding genetic materials have been requested by several laboratories internationally, including the United Kingdom, Czech Republic, Germany, Denmark, Kazakhstan, Russia, and Australia, in addition to the United States. Goodwin's research on gene expression during the resistance response identified early and late peaks of induction in response to $M$. graminicola. The late genes had not been implicated in plant defense responses previously and are the subjects of current research. Recent work with a barley microarray showed for the first time that nonhost responses of barley to $S$. tritici were different compared with R-gene responses to $S$. passerinii. This research shows considerable promise to offer new insights into the nature of nonhost resistance.

Goodwin's research impact is documented by 50 peer-reviewed publications, nine of which have been cited more than 100 times each. Citations over all his publications collectively total more than 2,500 . 


\section{Bradley I. Hillman}

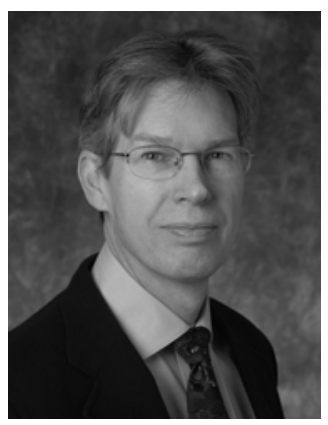

Bradley I. Hillman was born in Tucson, AZ. He received his B.S. degree from the University of California (UC) Berkeley in 1978 and his Ph.D. degree in 1986 also from UC Berkeley. As a Ph.D. student with Jack Morris, he focused on the molecular biology of Tomato bushy stunt virus, characterizing the first defective interfering RNAs of a plant virus and opening up a fertile research field in which hundreds of research articles have been published since that time. As a postdoctoral research associate with Andy Jackson at UC Berkeley, he investigated the plant rhabdovirus Sonchus yellow net virus. In 1987, Hillman initiated studies as a postdoctoral fellow with Don Nuss at the Roche Institute of Molecular Biology on viruses associated with hypovirulence of the chestnut blight fungus, Cryphonectria parasitica. He began a tenure-track faculty position at Rutgers University in 1989, rising to full professor in 2001. There, he has developed a program balanced between applied and basic research, including viruses and fungi. He has taught a number of different courses at Rutgers, including the undergraduate courses Comparative Virology and Perspectives in Agriculture and the Environment and the graduate courses Plant Virology, Principles of Plant Pathology, Advanced Plant Pathology, Introduction to Plant Biology, Seminar in Plant Pathology, Seminar in Plant Biology, and Presentation Skills. He has served as director for the graduate programs in plant pathology (3 years) and plant biology (4 years).

Hillman's research on fungal viruses has emphasized the wide array of viruses and transposons of $C$. parasitica. His published work has included the molecular characterizations of several viruses, including the first mitochondrial RNA virus of any organism; the first fungal member of the important virus family Reoviridae and establishment of the genus Mycoreovirus; identification of the first virus-resistant mutant of a filamentous fungus; identification of three of the four different species of the virus family Hypoviridae (the viruses responsible for most hypovirulence of $C$. parasitica); and the discovery of two transposons of $C$. parasitica.

His applied research at Rutgers has focused on virus diseases of blueberry and cranberry, two of the most important crops in New Jersey. This has included development and implementation of virus detection methods, characterization of the carlavirus associated with blueberry scorch disease, construction and manipulation of the first infectious cDNA clone for a member of the carlavirus group, and examination of the ecology and epidemiology of this carlavirus, the most important virus of blueberries. His group also characterized at the molecular level the caulimovirus that causes red ringspot disease of blueberry.

The third area of Hillman's research program concerns fungal diseases of turfgrass. The Rutgers Center for Turfgrass Research Science is known internationally and has a very strong and collaborative faculty. His research in this area has included examination of viruses of endophytic and epiphytic fungi, including the first molecular description of a member of the family Partitiviridae, investigation of the summer patch pathogen Magnaporthe poae, and most recently, examination of the members of the genus Colletotrichum responsible for anthracnose disease of turf and other grasses. The last project, with Bruce Clarke and JoAnne Crouch, Rutgers University, has become a major research focus. Recent studies from this group on the turfgrass pathogens have led to a redescription of the species, changing the designation from Colletotrichum graminicola to Colletotrichum cereale. Hillman's research program has been funded through individual or collaborative competitive grants to USDA NRI and NSF and by other public and private funding agencies.

Hillman's service record is exemplary. At Rutgers, Hillman has served as director of the graduate programs in plant pathology (1992-1995) and plant biology (1995-1998) and as vice chair of the Plant Pathology Department (1999-2001). He currently serves as director for research and senior associate director, New Jersey Agricultural Experiment Station (NJAES), as well as vice chair, Department of Plant Biology and Pathology, Rutgers University, a department of more than 50 faculty members. Hillman is or has been a member of NE-140 and NE-1015 regional research projects (1987-present; chair of NE-140, 1995); a member of four USDA NRI panels (panel manager, 2007); a member of the Rutgers University/Busch Biomedical Grants Panel (every year, 19962007); a member of the Executive Committee and chair of the Fungal Virus Subcommittee, International Committee for the Taxonomy of Viruses (1999-2005); in the Rutgers University Senate (2000-2003); and on many departmental, college, and university committees. Hillman has reviewed more than 300 manuscripts from 35 journals and more than 150 grants from 12 agencies since 1989 . He currently serves as editor for the journal Virus Research. Service to APS performed by Hillman has been extraordinary. He has served on the Virology Committee (19901993 and 1996-1999); on the Northeastern Division (NED) Graduate Student Award Committee (1990-1992; chair, 1992); on the NED Site Selection Committee (1993-1995); as an associate editor, Phytopathology (1995-1996); as a senior editor, Phytopathology (1996-1999); as editor-in-chief, Phytopathology (1999-2002); on the APS Publications Board (1999-2002; chair, 2000); on the APS Council (1999-2002); on the Ad Hoc APS Governance Committee (2001-2002); and on the Ad Hoc APS Awards Committee (2002) and has organized and participated in the Joint APS/MSA Discussion Session on Mycoviruses (2001 Annual Meeting, Salt Lake City).

Among his awards and honors are a Chancellor's Patent Fund Grant, UC Berkeley (1985); William Caroll Smith Fellowship, UC Berkeley (1986); Rutgers University Presidential Board of Trustees Fellowship for Scholarly Excellence (1995); Cook College/NJAES Research Excellence Award (1995); Team Research and Outreach Excellence Award (1996); USDA Group Honor Award for Excellence to NE140 Regional Research Project (1997); and Award of Merit, Northeastern Division of APS (2003).

\section{Charles M. Rush}

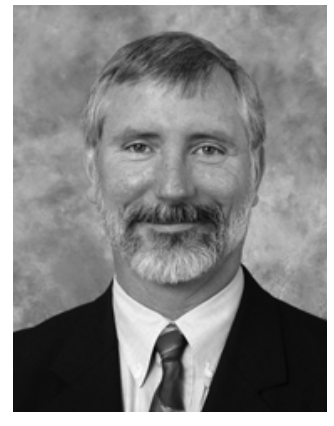

Charles M. Rush was born in Anthony, KS, and received a B.A. degree in literature from the University of Texas Permian Basin in 1974. He began his plant pathology studies at Texas A\&M University and received both the M. Agriculture (1976) and Ph.D. (1981) degrees under the direction of Stuart Lyda. He then conducted postdoctorate studies at the Texas Agricultural Experiment Station (TAES) at Temple, TX, and subsequently with the USDA ARS on pea and wheat diseases at Prosser, WA. In 1986, he was appointed associate professor in the Department of Plant Pathology and Microbiology at Texas A\&M University at the offcampus Texas AgriLife Research and Extension Center at Amarillo, where he now holds the rank of professor.

Rush is internationally renowned for studies of the epidemiology and ecology of soilborne pathogens of field crops with important contributions for managing diseases of wheat, sugar beet, and sorghum. In addition to addressing the major disease problems that impact production agriculture throughout the Great Plains, his desire to serve the needs of producers has led to devel- 
opment of a multifaceted program that prides itself in responsiveness to the ever-changing demands of large-scale production agriculture. For example, he readily assumed studies with newly introduced diseases, including sorghum ergot and Karnal bunt of wheat, where little was known of their ecology and epidemiology in the United States. In tackling these newly introduced diseases, he pioneered the application of radar-based rainfall measurement and developed regionally based, site-specific, risk assessment tools.

Rush's work with Karnal bunt has established him as an authority on the disease. He was instrumental in developing an integrated approach to this important disease of quarantine significance for wheat growers. His findings were used by USDA APHIS as scientific justification to deregulate fields that previously tested positive for the disease.

Rush is one of the foremost experts on benyviruses and is widely recognized for fundamental discoveries concerning the biology, ecology, and epidemiology of soilborne viruses with fungal vectors. Rush has gained international recognition for his work on the rhizomania virus disease of sugar beet, which threatens the U.S. industry with the emergence of new resistancebreaking strains of Beet necrotic yellow vein virus (BNYVV). His research has addressed virus evolution and population genetics of these viruses. Recently, his lab developed a molecular technique (allelic discrimination real-time PCR) to differentiate wild-type BNYVV from new, resistance-breaking strains that have emerged in California, thus paving the way for the development of resistant varieties.

Rush is additionally recognized for developing new methods to detect and quantify disease incidence and loss caused by Wheat streak mosaic virus (WSMV), which is the most widespread, economically damaging pathogen of wheat throughout the western Great Plains. Capitalizing on remote sensing tools and techniques he developed in precision agriculture studies, he investigated the impact of WSMV on crop water-use efficiency in dual purpose wheat to permit informed management decisions and new ways to conserve groundwater. These same technologies were used to measure losses from rhizomania and Cercospora leaf spot in sugar beet. As a result, he has been invited to lecture at the 9th International Congress of Plant Pathology in 2008 on this subject.

Rush has authored more than 70 refereed journal articles and 21 book chapters and served as editor of six books. Rush has been awarded two U.S. patents for a novel method of plant inoculation (1997) and for a gene delivery system (2001) for the sugar beet benyviruses. He receives impressive funding for his research as evidenced by grants exceeding \$2.5 million since 2001 from federal, state, industry, and commodity sources.

His expertise and knowledge gained from research has been extended to others as a chair/organizer of many different symposia and workshops. He provided valuable service as TxGrain program coordinator for sorghum ergot research, served as committee chair for NC1015 that secured a congressional initiative to fund research aimed at developing strategies to control Karnal bunt of wheat, and organized the first symposium for the High Plains virus when it appeared in the mid-1990s.

Rush takes great pride in having trained graduate students, technicians, and postdoctoral associates who have gone on to productive careers in the plant sciences. Rush actively serves as major professor for graduate students interested in developing integrated approaches to plant disease control. He has cochaired or served as a member of 19 graduate student committees and has trained numerous postgraduate professionals, six of whom now hold faculty positions at land-grant universities. In addition, Rush served as major advisor to numerous undergraduate interns in West Texas A\&M University's Co-op Internship Training Program.

Rush has a distinguished record of service as exemplified by membership on numerous departmental and university committees, contributions to APS and other scientific societies, and participation on a variety of regional and national scientific review panels. Rush has provided valuable service to his profession through participation on several APS editorial boards, including terms as associate editor for Plant Disease and Phytopathology and as senior editor for Plant Disease. Because of his track record of success, he has been awarded a number of professional and scientific honors, including the Texas Agricultural Experiment Station's Faculty Fellow and Regent's Fellow Awards in 2007 for research accomplishments and scientific leadership. He also was honored with the Outstanding Achievement Award in Education from the University of Texas Permian Basin, the Meritorious Service Award from the Beet Sugar Development Foundation, and the Distinguished Service Award from the Minnesota/North Dakota Sugarbeet Research and Education Board.

In summary, Rush has provided outstanding scientific leadership as a plant pathologist. He has a distinguished record of professional service and is a strong advocate for interdisciplinary approaches to crop and disease management. Rush has achieved international recognition for his work with rhizomania and the emergence of new resistance-breaking strains of BNYVV. His studies on the nature and control of fungal and virus diseases of field crops are recognized as important models for studying the epidemiology and population genetics of pathogens.

\section{Jonathan Walton}

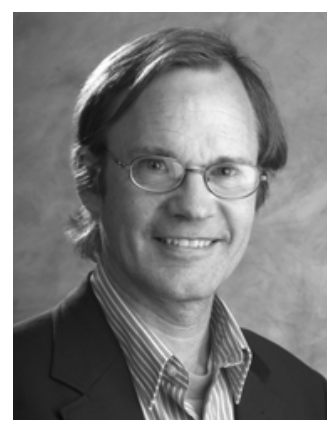

Jonathan Walton received his B.A. degree in biology from the University of California, Santa Cruz. He received his master's degree in plant pathology from Cornell University, working with Olen Yoder, Elizabeth Earle, and Roger Spanswick on the mode of action of Ttoxin from Cochliobolus heterostrophus (Helminthosporium maydis), and his Ph.D. degree from Stanford University in 1982. He then returned to Cornell to work with Elizabeth Earle on the structures and modes of action of host-selective toxins, including HC-toxin and victorin from $C$. carbonum and $C$. victoriae, respectively. After a year at the University of Rome, working with Alessandro Ballio on fusicoccin receptors, he took a position at the former ARCO Plant Cell Research Institute (Dublin, California), where he began to study the enzymology of HC-toxin biosynthesis. In 1987, he moved to the Department of Energy (DOE)-Plant Research Laboratory and the Department of Plant Biology at Michigan State University (MSU). Here, he continued his studies on the maize-C. carbonum system and the HC-toxin.

Walton's program has lead to the molecular characterization of the genetic locus (TOX2) controlling HC-toxin production, including one of the first characterizations of a gene for a multidomain nonribosomal peptide synthetase. Related studies in his lab (in collaboration with Guri Johal and Steve Briggs, then at Pioneer Hi-Bred International) demonstrated that the $\mathrm{Hml}$ resistance gene in maize encodes an enzyme that detoxifies HCtoxin. This was the first disease resistance mechanism that had ever been identified, and the ensuing publications were landmarks in this important area of plant research. Furthermore, his lab (in collaboration with Peter Loidl and coworkers at the University of Innsbruck) identified histone deacetylase as the site of action of HC-toxin. This exciting discovery directly links pathogenesis with interference in host gene regulation. Thus, Walton's discoveries provide an extraordinarily comprehensive understanding of a pathosystem, including the chemical structure, the pathway of synthesis, the mode of action of the pathotoxin, and the biochemical basis for genetic resistance against it.

Interestingly, Walton and coworkers recently showed that the cyclic peptide toxins of poisonous Amanita mushrooms are 
synthesized on ribosomes and not, like HC-toxin and other fungal cyclic peptides, by nonribosomal peptide synthetases.

Walton has also made contributions to our understanding of the role of cell-wall-degrading enzymes in virulence, including identification of $S N F 1$ as a regulator of enzyme expression and virulence in plant-pathogenic fungi. Using modern tools of proteomics, he demonstrated the feasibility of detecting numerous fungal proteins in infected plant tissue, many of which are degradative enzymes. His work in this area led to his current interest in the application of cell-wall-degrading enzymes to the deconstruction of lignocellulosic materials for bioenergy production. As a world authority in this area, Walton has recently been appointed associate director of the DOE-funded Great Lakes Bioenergy Research Center at MSU.

Walton has been a dedicated teacher of undergraduate students. $\mathrm{He}$ is passionate about teaching junior scientists the thrill of conducting scientific research, demonstrating his enthusiasm by working alongside them at the bench and setting a personal example of experimental rigor and creativity. He has trained a large number of graduate students and postdoctoral research associates, many of whom have moved on to productive careers of their own, as well as undergraduate students who performed their senior research projects in his laboratory.

Walton has served as editor-in-chief of the newsletter of the International Society for Plant-Microbe Interactions (IS-MPMI Reporter), on the board of directors of IS-MPMI, and as president of IS-MPMI (2003-2005). He has been a senior editor of Molecular Plant-Microbe Interactions and is currently the editorin-chief of $M P M I$, in which role he also serves on the APS Publications Board. He has also served on the editorial boards of the Annual Review of Phytopathology and Eukaryotic Cell. In 2002, he received the MSU Distinguished Faculty Award.

\section{Michael J. Wingfield}

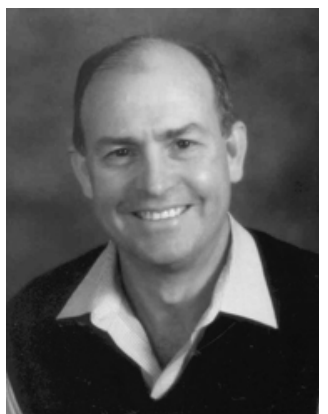

Michael J. Wingfield was born in 1954 in Natal, South Africa. He received a B.Sc. degree in botany and plant pathology from the University of Natal in 1976 and, the following year, received a B.Sc. Honors degree in plant pathology from the same university. In 1979, he received an M.Sc. degree in plant pathology from the University of Stellenbosch and married Brenda D. Fairbairn, his life partner and colleague (professor, Department of Genetics, University of Pretoria). Wingfield established the first formal forest pathology research program in South Africa in 1978 at the Plant Protection Research Institute in Stellenbosch and, after completing his Ph.D. degree in 1983 (University of Minnesota: major, plant pathology; minor, entomology), returned to resume development of that program. He moved to the University of the Free State in 1988 and became a full professor in the Department of Microbiology and Biochemistry in 1990. In 1994, he was appointed to the Mondi Paper Co. Ltd. endowed chair in forest pathology, a position he still holds. Wingfield is the founding and current director of the Forestry and Agricultural Biotechnology Institute (FABI) at the University of Pretoria, where he also is a professor and member of senate. Concurrent with his other appointments, he is director of the Department of Science and Technology/National Research Foundation, Centre of Excellence in Tree Health Biotechnology, one of the first six established as part of the government-supported science system.

Wingfield is an internationally respected plant pathologist and one of the most influential forest scientists in the world. His research has had a major impact on forest pathology, mycology, and forest health management, with major contributions in research, teaching, and administration. He is a prolific, original investigator who has authored or coauthored more than 500 refereed publications, five books, and numerous chapters in books and proceedings. Wingfield has ongoing projects and collaborations in many parts of the world, and his research has enhanced understanding of some of the most complex and damaging diseases of pines, eucalypts, and other important trees. Pathogens of special interest, and to which he and his students have contributed new knowledge, include species of Ceratocystis, Ophiostoma, Mycosphaerella, Fusarium, Cryphonectria, and Armillaria. His research on insects that interact with and/or vector some causal agents of tree diseases is seminal. His team has coupled molecular and classical techniques to identify, characterize, and differentiate pathogens; delineate new, often cryptic species; and discern phylogenetic relationships. Findings from this basic research have had real-world applications in diverse areas, including the development of host resistance, international quarantines, and disease management.

Wingfield is deeply committed to education and is an enthusiastic and creative mentor. He has taught numerous courses at the university level and still teaches undergraduate classes and delivers guest lectures in plant pathology, genetics, and botany at the University of Pretoria. He has advised or served on the committees of more than 80 M.Sc. and Ph.D. students, many of whom now lead their own programs on five continents. Wingfield is a frequent global consultant on forest diseases and insects and is in demand as a speaker at scientific meetings. He has given more than 100 invited plenary or keynote addresses worldwide.

Wingfield's outstanding administrative contribution has been the founding and development of the FABI on the campus of the University of Pretoria (www.fabinet.up.ac.za). In 1997, Wingfield's vision for the new institute was translated into reality with the relocation of 55 scientists in South Africa, construction of a major new building, and implementation of a broad research initiative. In only a decade, FABI has become one of the world's most recognized and most productive forest protection and agricultural biotechnology research centers with more than 110 academic staff, postdoctorates, and Ph.D. and M.Sc. students. FABI engages the single largest number of plant pathologists in South Africa; is a major center for the investigation of forest and agricultural problems, especially in Africa, South America, and Southeast Asia; and is a training center for young forest protection specialists worldwide.

Wingfield has served the discipline of plant pathology in diverse capacities, including president of the Southern African Society of Plant Pathology; vice president of the International Society for Plant Pathology; coordinator of the Forest Health Division, International Union of Forestry Research Organizations; and Editorial Board member for Mycological Research, Plant Pathology, Australasian Plant Pathology, and the Encyclopedia of Forest Sciences. Wingfield's productivity, contributions, and tireless efforts on behalf of forestry and agriculture have been recognized with numerous awards. Among the most prestigious are the Scientific Achievement Award of the International Union of Forestry Research Organizations; Havenga Prize of the South African Academy for Art and Science; gold medal of the South African Association for the Advancement of Science; the highest award of the South African National Science and Technology Forum; and Distinguished Plant Pathology Alumnus of the University of Minnesota. He is a member of the Academy of Science of South Africa, fellow of the Royal Society of South Africa, honorary member of the Mycological Society of America, and fellow of the South African Society for Plant Pathology (SASPP). In 1998, he became the third recipient of the highest award from SASPP, the Hendrik Christian Persoon Medal (after J. E. van der Plank and W. F. O. Marasas). Wingfield has had three fungi named in his honor: Leptographium wingfieldii Morelet, Sterigmatomyces wingfieldii van der Walt, and Asterina wingfieldi. 


\section{Shyi-Dong Yeh}

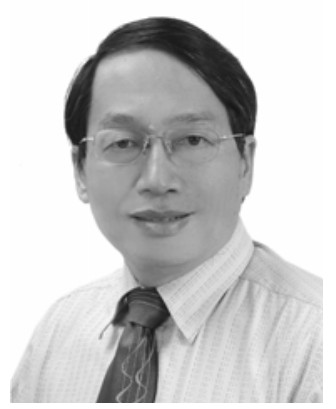

Shyi-Dong Yeh was born and raised in Taiwan, Republic of China, and earned his B.Sc. (1974) and M.S. (1979) degrees in plant pathology from National Chung Hsing University. He matriculated to Cornell University and received his $\mathrm{Ph} . \mathrm{D}$. degree in plant pathology in 1983. Yeh then joined the Plant Pathology Department of the National Chung Hsing University in 1984 and was promoted in 2006 to chair professor of plant pathology, one of only nine chair professors of the university. In 2004, Yeh was appointed as the vice president of National Chung Hsing University. Yeh's extraordinary contributions to fundamental and practical virological research are documented in his more than 90 publications.

Yeh's research has always targeted economically important viruses with the aim of developing effective control measures. This philosophy is shown by his works on Papaya ringspot virus (PRSV), Zucchini yellow mosaic virus (ZYMV), and tospoviruses. During his Ph.D. research, Yeh developed a mild nitrous acid mutant of PRSV and he subsequently led the effort to deploy the mild PRSV in large-scale cross-protection of papaya in Taiwan. Yeh was the first to show that PRSV RNA is translated into a polyprotein that is subsequently cleaved into functional protein products, the first to sequence the PRSV genome, and the first to develop infectious transcripts of the virus. He then proceeded to reveal the viral determinants for symptom attenuation, viral movement, local lesion expression, host range, and viral-induced suppression of gene silencing. He showed that symptom attenuation of PRSV was due to mutations in the P1 and HC-Pro genes and that the differences in host range of the cucurbit-infecting PRSV$\mathrm{W}$ and the cucurbit- and papaya-infecting PRSV-P types are due to mutations in the NIa and NIb regions of the genome. Using this knowledge, Yeh has "custom-made" mild strains of PRSV that are highly effective in cross-protecting against PRSV in cucurbits.

Yeh's ability to use a variety of technologies and fundamental knowledge toward a practical end is again illustrated by his development of PRSV-resistant transgenic papaya. His laboratory developed transgenic papaya that showed excellent resistance to a range of PRSV isolates from different countries and performed well in field trials. The transgenic papaya is now going through the process of deregulation in Taiwan and could be the first transgenic papaya to be deregulated outside the United States. Following the observation that a specific naturally occurring strain of PRSV overcame the transgenic resistance, Yeh constructed a recombinant PRSV to show that the HC-Pro gene of the naturally occurring PRSV suppressed the gene silencing in the transgenic papaya to overcome its resistance. His lab recently developed a new transgenic papaya with resistance to PRSV and Papaya leaf distortion mosaic virus, which he had recently discovered in Taiwan.

In the late 1990s, Yeh began to develop mild strains of ZYMV for controlling ZYMV by cross-protection. Infectious transcripts of ZYMV were developed and used to develop fundamental knowledge on the sequence determinants that govern symptom expression, viral movement, and host range. This information was then used to create mild recombinant strains of ZYMV, which conferred effective cross-protection against ZYMV in cucurbits.

Yeh has greatly advanced the field of tospoviruses, especially in Asia. Early on, people assumed that Tomato spotted wilt virus was the main tospovirus in Taiwan. Instead, Yeh identified three new tospoviruses as the prevalent ones in Taiwan. He then proceeded to serologically and molecularly characterize these viruses. Yeh produced polyclonal and monoclonal antibodies against the nucleocapsid proteins of the five major serogroups of tospoviruses and also produced a monoclonal antibody that is effective in detecting most Asian tospovirus species. These antibodies are now widely used for detecting and characterizing tospoviruses. Furthermore, Yeh identified and demonstrated that degenerate primers designed from the conserved regions of the $\mathrm{L}$ genes of tospoviruses can be used as a genus-specific tool for detection of tospoviruses by RTPCR. His lab has led the effort to organize all reported tospoviruses by proposing a new classification scheme of the 16 current species based on their phylogenetic and serological relationships.

Yeh has also pioneered the use of potyviruses as vectors for producing useful proteins in plants. His lab constructed a modified ZYMV as a vector to express tospovirus proteins and a mite allergen (Der p 5) in cucurbits. The isolated mite allergen was subsequently tested in mice and shown to down regulate allergeninduced airway inflammation and immunoglobulin E synthesis when administered orally. Most recently, Yeh has characterized the effectiveness and stability of heterologous protein expression in plants by using Turnip mosaic virus. This research has established the optimal conditions for the use of potyvirus vectors for expressing a range of proteins in plants, including those with pharmaceutical value.

The ever-expanding quest of Yeh's laboratory for developing effective means to control plant viruses can be seen in his collaborative work with Nam-Hai Chua of Rockefeller University. They recently showed that small transgenes consisting of artificial micro RNAs confer resistance to plant viruses. This approach has the promise to be simple and effective for designing transgenes to confer virus resistance.

The contributions of Yeh to his country go far beyond research. He established the modern virology program at National Chung Hsing University and has been the major professor for 40 M.S. and 10 Ph.D. students. He served as the director of the Biotechnology Center for National Chung Hsing University and chaired the Plant Biotechnology Resources Center for promoting biotechnology education for the five national universities of Taiwan. Under his guidance as vice president of National Chung Hsing University for scientific affairs, the government awarded the university a 5-year funding of 13 million U.S. dollars annually to promote National Chung Hsing University as one of the top universities in Asia in agricultural biotechnology. The international and national recognition of Yeh is evidenced by his more than 40 invitations to speak at international scientific conferences and numerous outstanding research awards.

\section{Thomas A. Zitter}

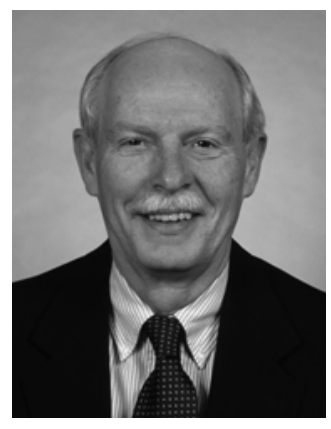

Thomas A. Zitter was born in 1941 in Saginaw, MI, and received his B.S. degree in botany (1963) and his Ph.D. degree in plant pathology (1968) from Michigan State University. Zitter has served on the faculty of the University of Florida (1968-1979) and Cornell University (1979-present). Zitter has been a leader in plant pathology research and extension in service to the vegetable industry for nearly 40 years.

Zitter is one of the most respected vegetable crop pathologists in the United States today. His problem-solving research and his educational programs benefit vegetable producers in the northeast and across the nation. Walter R. Stevenson, professor of plant pathology and the Friday chair of vegetable production research at the University of Wisconsin, writes, "I strongly support the nomination of Dr. Thomas Zitter for the APS Fellow Award. He has provided a wealth of information to the vegetable industry that is helping to improve management and reduce losses. His Vegetable MD web site is clearly the best site available for science-based information re- 
garding disease diagnosis, pathogens, and management information on vegetable diseases."

Zitter is an exemplary extension educator. He is widely admired by the growers for his willingness to address their needs with timely, unbiased, and useful information. This was a large factor in Zitter's selection as recipient of Cornell's College of Agriculture and Life Sciences Award for Extension and Outreach in 2000, the Excellence in IPM Award from the New York State IPM Program in 2002, and the APS Excellence in Extension Award in 2002. Zitter's U.S. colleagues have acknowledged his leadership in extension in several ways. He has served as a representative of extension plant pathology on CSREES departmental review panels at the University of Florida, North Carolina State University, Purdue University, and the University of Kentucky. He was elected and served as chair of the APS Extension Committee in 1987-1988 and he remains an active contributor to that committee. He has also served APS in numerous other ways.

Zitter's applied research and extension programs are a continuum. Throughout his career, Zitter has contributed to applied knowledge in plant virology, conducting studies on maize white line mosaic and its satellite virus infecting sweet corn, on infection of pepper by cucumber mosaic cucumovirus, aimed at understanding the epidemiology of cucurbit viruses, and on potato Y potyvirus and potato leafroll luteovirus infection of potato. The pressing need to find immediate solutions for the control of fungal diseases lead Zitter in the direction of fungicide usage for potato seed piece treatments and foliar disease control of tomato early blight and several cucurbit diseases. His work with tomato early blight looked at ways to minimize fungicide sprays through the use of disease forecasting systems, alternative materials such as bicarbonates and mineral oils, use of foliar nitrogen sprays, and sprayer application technology including the use of air-assisted, electrostatic sprayers. His fungicide evaluations have provided necessary data for the approval of fungicides for the control of early and late blight of tomato. Zitter first described Ulocladium leaf spot on cucumbers in the United States and identified sources of resistant germplasm. He also identified new sources of muskmelon germplasm with resistance to gummy stem blight and utilized PCR specific probes to distinguish the gummy stem blight pathogen, Didymella bryoniae, from Phoma species. He described the distribution of Fusarium wilt of melon in New York and identified race 1 of the pathogen in the state for the first time. He showed that harpin protein (Messenger) reduced colonization of plants by insects. He utilized a biotype of Alternaria tomatophila identified in his lab as highly pathogenic on tomato to demonstrate that homozygous resistance is necessary in tomato varieties to combat this pathogen. He is currently working with others to incorporate Septoria leaf spot resistance into tomato varieties that also resist early blight and late blight. He is doing innovative research on the integration of least-toxic materials into the management of diseases in potato, tomato, and cucurbits.

Zitter has been a leader in developing disease reference materials and control recommendations. He served as editor for two disease compendia published by APS PRESS, Compendium of Tomato Diseases (two different editions) and Compendium of Cucurbit Diseases. He has authored more than 30 Cornell vegetable disease fact sheets and bulletins. Each of these publications has been received extremely well by diverse audiences. Zitter conceived and developed a comprehensive and attractive web site, Vegetable MD Online (http://vegetablemdonline.ppath.cornell.edu/), as a convenient tool for use by anyone interested in the diagnosis and management of vegetable diseases. The site, which includes more than 70 disease fact sheets and more than 500 illustrations in a photo gallery, has attracted worldwide attention. In 2001, Vegetable MD Online earned Zitter the American University Award for Educational Excellence in Web Page Development. In 2006 alone, the web site received more than 1.5 million "hits", which places Vegetable MD Online in the top tier of popular science web sites. And Zitter continues to add valuable content to the site. The latest additions are diagnostic keys for tomato and cucurbits.

Another of Zitter's legacies is the comprehensive program he has developed for plant disease management on cucurbits, integrating scouting, accurate diagnosis, cultural practices, variety selection, and decision guidelines for fungicide selection and application. He was senior editor for the New York Cucurbit IPM Scouting Procedures utilized in New York and surrounding states. In concert with colleagues, Zitter has organized several cucurbit workshops that were well attended by growers from several northeastern states. Zitter's contributions to cucurbit production have also led to several invitations to address national and international audiences, including an international symposium on cucurbits in Adana, Turkey, and a melon symposium at APS Caribbean Division meetings.

Zitter is among the very best extension educators and applied researchers that the profession of plant pathology has produced. Zitter is highly deserving of the APS Fellow Award.

\section{Excellence in Extension Award}

This award recognizes excellence in extension plant pathology.

\section{Mary K. Hausbeck}

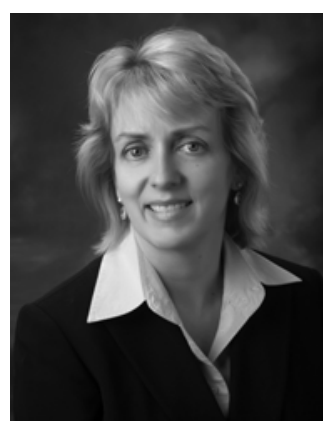

Mary K. Hausbeck was born in Saginaw, MI. She received B.S. and M.S. degrees in horticulture from Michigan State University (MSU). In 1990, she received her Ph.D. degree in plant pathology from Pennsylvania State University, under the guidance of Stan Pennypacker. In 1990, she returned to MSU as visiting assistant professor of plant pathology and was appointed in the tenure stream in 1992. She was promoted to associate profes- sor in 1998 and to full professor in 2002. Throughout her career at MSU, Hausbeck has been responsible for extension and research on diseases of greenhouse ornamentals and a wide array of vegetable crops. Her appointment is currently $60 \%$ extension/40\% research.

Hausbeck has established an extension and research program in the biology, management, and epidemiology of diseases of vegetables and greenhouse ornamentals that is nationally and internationally recognized for its excellence and responsiveness to industry needs. Her service to the vegetable and greenhouse ornamentals industries is exceptional and has been recognized by numerous awards. These include the Distinguished Faculty Award from the MSU Agriculture and Natural Resources Alumni Association, the Alex Laurie Award from the Society of American 
Florists, and the outstanding MSU Extension Specialist Award. Hausbeck has also received several team awards, such as the John Hannah Award for Program Excellence from the Michigan Council of Extension Agents and the West Central Region Team Award for Excellence in Extension Programming.

Her extension and research programs are tightly integrated. This is clearly shown by the close interactions she has with growers, consultants, extension educators, and other researchers as she addresses disease problems and possible solutions. She has worked with growers who manage small farms to those who have hundreds of acres in different locations. She conducts some research on grower cooperator farms, and this allows for realworld tests of new disease management approaches and serves as excellent demonstrations for her extension program. An example of this success was working with a grower cooperator to obtain the needed epidemiological data for a forecasting system for purple spot of asparagus. From this one grower, the forecasting system was piloted with other growers in cooperation with an extension educator and now this system is a well-established tool for this industry.

Hausbeck knows how to deliver information to her growers and clientele groups. She has coordinated or contributed to more than 60 workshops and tours. Of note are the workshops she has presented in which the growers receive hands-on experience with the pathogens and diseases that threaten their industries. For example, Phytophthora workshops have provided growers with a better understanding of the pathogen and how best to deal with an increasingly serious disease of vegetables. These require a tremendous amount of planning, but this is typical of the care that she puts into all of her work. She is in great demand as a speaker and has presented well over 260 extension talks in Michigan, 95 in other states, and 8 in other countries.

Hausbeck has been a driving force in the development of five specialty crop strategic pest management plans that evolved out of workshops in which she brought together researchers from Michigan and other states, growers, and government agencies. These plans have been invaluable to the industry and have served as national models for how these plans should be developed. The development of these plans illustrates her ability to effectively bring scientists and the industry together to assess industry needs and determine how best to address these needs. As a result of these plans, she developed several successful USDA grants.

Hausbeck has been a prolific producer of extension materials. She has authored 74 magazine articles, coauthored several extensive pest and disease management bulletins, and has written 319 articles for MSU Crop Advisory Team Alerts for vegetables and for greenhouse crops. She also has authored 130 meeting proceedings papers-most of which are for large industry meetings, such as the Great Lakes Expo. These papers ensure that the growers attending the meeting will take home the most up-to-date disease and disease management information.

Her research also forms the basis for disease management recommendations as well as provides the efficacy data that is critical to ensure that the most effective products are available to the growers. She regularly works with state and federal agencies and has obtained 17 Section 18 emergency exemptions and five critical use exemptions from EPA. She works closely with the IR4 program to also ensure that disease management materials are being tested in Michigan.

Hausbeck has also served APS in several ways. Among these include membership on several committees and a section editor for Fungicide and Nematicide Tests. She also served as senior editor for Plant Disease, which further indicates how well she is respected by her peers. Finally, Hausbeck takes graduate education very seriously and has been a mentor for 4 Ph.D. and 15 M.S. students. Her program presents excellent, real-world problems on which students can develop their thesis research and provides them with the background to follow a career in extension if they so desire. She also instills a high degree of professionalism in her students and gives them the tools to be successful.

Hausbeck clearly understands the needs of the industries she serves and knows how to assist them through high-quality extension that is firmly grounded in research. She has presented 58 invited talks and has published 60 refereed papers and nearly 300 research reports that provide the information used in her extension program. She accomplishes so much high-quality work that a colleague commented that there must be several "Mary Hausbecks" in Michigan. However, there is only one Mary Hausbeck and it is her dedication, organizational skills, and teamwork approach that allows her to accomplish so much.

\section{Excellence in Industry Award}

This award recognizes outstanding contributions to plant pathology by APS members whose primary employment involves work outside the university and federal realms either for profit or nonprofit.

\section{Christopher M. Becker}

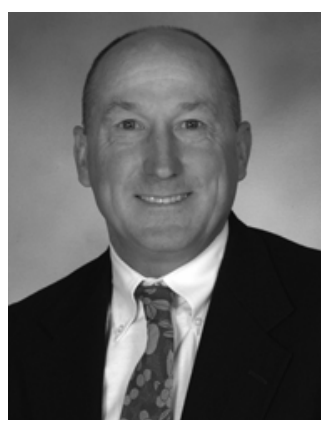

Christopher M. Becker was born in Neptune, NJ. He received a B.S. degree in botany from the University of Vermont in 1979 and M.S. and Ph.D. degrees in plant pathology from the University of Massachusetts (1983) and Cornell (1990), respectively. Becker has had extensive experience in industry, which has included working both for large agricultural chemical companies as well as starting his own small applied agricultural research company. Throughout his career, he has focused on applied plant pathology and has enjoyed applying his work to providing solutions to
American growers. Becker has also been highly devoted to The American Phytopathological Society throughout his career and he has positively influenced the close relations that industry and APS have today.

As an agriculturist or field biologist for 10 years, Becker was responsible for conducting targeted research with fungicides, insecticides, herbicides, and plant growth regulators on northeastern crops. His expertise in field pathology was extremely broad since he conducted trials on fruit, vegetables, turf/ornamentals, and greenhouse crops. Becker also had a passion for teaching others about plant pathology, either in a formal setting or just in conversation. Becker is well-known and greatly appreciated by the technical community that he influenced: technical service representatives, agricultural chemical dealers and salesmen, and farmers. While working for Cyanamid and BASF, Becker established several training classes for his fellow 
colleagues. Becker also conducted several field training courses for growers, commodity group personnel, and university/extension faculty, as well as his fellow industry peers. Some of the specific titles of training courses that he developed and taught include Fungicide Mode of Action, Basic Plant Pathology, and Optimum Management of Crops and Disease Interactions for Fungicide Trials in the Field. Becker's enthusiasm for plant pathology was always reflected in these courses since they were always well received.

One of Becker's most significant contributions was his dedicated field research with the development of dimethomorph (Acrobat). During the 1995-1998 late blight years, Becker personally conducted numerous late blight trials, and he was responsible for summarizing global data from Phytophthora infestans, P. capsici, tobacco blue mold, and a diversity of downy mildew trials. This laborious data summary greatly expedited the development and positioning of Acrobat fungicide in the U.S. market. Becker was also instrumental in launching Acrobat in the United States, and he was responsible for introducing it to the APS members as he delivered eight presentations on Acrobat over 7 years.

Following the elimination of all the field biologists within BASF, Becker formed BAAR Scientific, LLC. As the president and research scientist of BAAR Scientific LLC, Becker consults with Finger Lakes grape growers in New York by providing knowledge-based pest management services and interacts with large and small agrichemical companies in order to evaluate pest management products under northeastern U.S. conditions. More than $50 \%$ of the field research that Becker conducts is with fungicides, thus the justification for BAAR Scientific LLC to become a sustaining associate member of APS.

Becker has always been highly involved and dedicated to APS throughout his career. Probably his most significant service to APS arose following nomination as the director to the newly formed Ad Hoc Industry Committee in 1999. Within that committee, he used his organizational and listening skills to identify that APS and the industry sector would benefit mutually from a council-level board that fostered interactions between APS and industry members. As a result of laborious and challenging efforts, the Office of Industry Relations was established within APS, and Becker was approved as the first director. Becker held this position from 2001 until 2004. Becker was nominated as a senior editor for APS PRESS, which he served from 2000 to 2002. In addition, Becker has maintained membership on the Industry Committee, which he also chaired in 1997. Becker also served as the industry liaison for the "Materials under Trial" database used within Fungicide and Nematicide Tests. This $>3,000$ line list of products has improved Fungicide and Nematicide Tests by standardizing how products are listed for readers and authors. Becker was also highly involved in the Northeastern Division of APS, where he served as president in 1999, vice president in 1998, and secretary/treasurer in 1997. As an officer of the Northeastern Division of APS, Becker was instrumental in the expansion of symposiums and workshops as part of the divisional APS meetings. The focused workshops were extremely successful at reaching beyond traditional APS members. The additional workshops at the divisional meetings were effective at drawing larger audiences, which reduced fees on a "per attendee" level. In addition, the added workshops at the generally applied-focused divisional meetings provided increased interactions that optimized disease control with a larger audience for industry personnel, university researchers, and extension faculty scientists. Becker also was one of the champions who organized the joint meetings between the Northeastern and Potomac Divisions. The resulting meetings were positive scientific and networking opportunities, especially since both regions shared similar crops and plant diseases. Due to the positive outcome of the joint divisional meetings, the cosponsored joint meetings are now scheduled on a 4- or 5-year rotation.

\section{Excellence in Teaching Award}

This award recognizes excellence in teaching plant pathology.

\section{Michael J. Boehm}

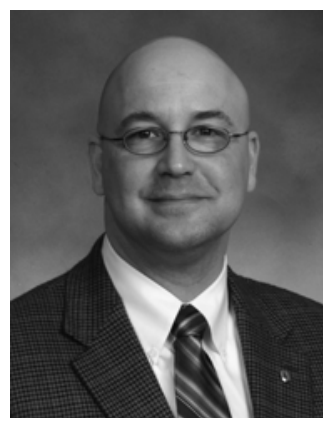

Michael J. Boehm was born and grew up in Ohio, earning a B.S. degree in biology from Heidelberg College and M.S. and Ph.D. degrees in plant pathology from The Ohio State University. After graduation, he took a postdoctoral position with the USDA ARS in Corvallis, OR, to work on biocontrol research. His dedication to teaching was already so great, however, that he volunteered to teach the Introductory Plant Pathology course at Oregon State University (as a sabbatical replacement). Because of his profound interest in undergraduate teaching, reinforced by his positive experiences at Oregon State University, he took a position as an assistant professor at Monmouth College in Illinois, where he taught several biology and microbiology courses. Because of his reputation as a dedicated, innovative, and caring teacher, he was recruited back to Ohio State University in 1996 as an assistant professor in plant pathology.
Since his arrival at Ohio State University, Boehm has had responsibility for two turfgrass disease and pest management courses, taken primarily by undergraduates. Because of the great job he did with these courses, and the outstandingly positive feedback from the students, the department quickly gave him responsibility for its "flagship" introductory course, Plant Pathology 401, which he taught from 1997 to 2006. This is the key course for all future study in plant pathology and the only exposure many students ever have to the discipline, so the department takes the course very seriously. As expected, Boehm showed that he was the perfect person to teach this course. Boehm has a reputation as a demanding but caring instructor. His overall student-evaluation scores are consistently high, considerably above the university and college averages. Student responses reflect these high scores. Example comments include "...one of the most challenging, informative and overall helpful professors I have ever had...;" "...got the impression that Boehm would stand on his head if it would help a student understand a fact or process...;" and "...you are motivational as well as educational. I can look at you as a role model...." In 2005, Boehm put his time as a bio-threat agent testing specialist with the U.S. Navy to use and assumed responsibility for teaching a 
newly developed course for liberal arts majors called "Bioterrorism: An overview."

Boehm is well-known on campus for his use of problem-based or real-world practicums in his courses, especially his Integrated Turfgrass Health Management course. Students are required to work with golf course superintendents or professional sports turfgrass managers to determine their specific problems, ask probing questions, and then develop a comprehensive integrated turfgrass health management plan to meet their needs. In its current form, students are divided into small working groups and assigned to work with a particular golf course. The students spend time throughout the quarter working with the course's superintendent, listening to concerns, making onsite visits, taking and analyzing soil and tissue samples, and reviewing the superintendent's records. Throughout these experiences, Boehm infuses informational sessions-discussions, lectures, invited guest speakers, and field trips - that provide additional information the students have requested or believe they need to successfully complete the project. The final outcome of the student's efforts is the development of an integrated turfgrass health management plan for the golf course, presented to the superintendent and the leadership of the golf course. Besides solidifying their understanding of integrated turfgrass health management, the project provides ample opportunities for the students to hone their formal presentation, computer, people management, and interpersonal communication skills. This problem-based approach forces students to think out of the box and focus their attention on key concepts and issues, making the students better prepared to integrate theory and application. Recently, Boehm introduced a new "twist" to the pest management course-he developed a new course called "Integrated Turfgrass Health and Pest Management—New York Style." He received a grant from a newly constructed golf course on Long Island (Sebonack Golf
Club) to cover the costs associated with a special study tour to Long Island and New York City to study integrated turfgrass health management practices in this environmentally sensitive region of the United States. This year's class is headed to St. Louis.

In addition to his teaching, Boehm has also been very active in curriculum development and mentoring. Most recently, he was instrumental in overseeing the development of two new creditbearing graduate courses in mentored teaching: Plant Pathology 901 (mentored teaching in plant pathology) and Plant Pathology 902 (mentored extension/outreach teaching in plant pathology). The courses are designed to pair students-either one-on-one or in small groups-with a mentor (faculty or extension educator) to gain experiences focused on direct interactions with students or extension clientele and on the scholarly aspects of teaching. Since joining the faculty at Ohio State University, Boehm has also been actively engaged in advising students. To date, he has advised four postdocs, five visiting scientists, 10 graduate students, and 40 undergraduate students and has served on the advisory committees of an additional 21 graduate students. Boehm has been recognized numerous times at the department, college, and university levels for his dedication to teaching and learning.

Boehm has been recognized numerous times for his teaching accomplishments. Of special importance is the receipt in 2000 of the Ohio State Alumni Award for Distinguished Teaching, the only person in plant pathology to be so recognized. He also received the Outstanding Professor Award four times from students in another department and the Pomerene and Gamma Sigma Delta Teaching Awards from the college. Boehm is an active member of APS, where he currently serves as the junior councilor-at-large and on various committees and strategic planning boards. Boehm was appointed as chair of Ohio State University's Department of Plant Pathology in July 2007.

\section{International Service Award}

This award recognizes outstanding contributions to plant pathology by an APS member for a country other than his or her own.

\section{Randy C. Ploetz}

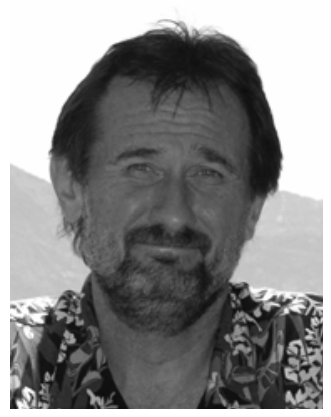

Randy C. Ploetz was born in Gastonia, NC, where his father pitched for a minor league baseball team. He graduated from Purdue University in 1974 with a B.Sc. degree in forestry and in 1976 with a M.Sc. degree in plant pathology. In 1984, he received a Ph.D. degree in plant pathology from the University of Florida and, in 1986, joined the faculty at the university's Tropical Research and Education Center in Homestead, where he was promoted to professor in 1996.

Ploetz's primary research responsibilities are on diseases of tropical fruits, many of which are important commercial crops in southern Florida. This position involves significant work overseas, where he advises students and research projects, participates in and organizes scientific meetings, assesses new disease outbreaks and the status of other important problems, and consults for international agencies and producers. He has ongoing collaborations in several countries and has worked in 34 since 1990 (Australia, Austria, Bahamas, Benin, Bolivia, Brazil, Burundi, Canada, China, Colombia, Costa Rica, Ecuador, Egypt, France, Honduras, Indonesia, Israel, Jamaica, Malawi, Malaysia, Mexico, Nicaragua, Nigeria, Oman, Peru, Rwanda, South Africa, Spain, Swaziland, Taiwan, Thailand, Uganda, United Arab Emirates, and the United Kingdom). Ploetz has been an invited plenary speaker at 37 international conferences and symposia, has advised 15 M.Sc. and Ph.D. students, and served two consecutive terms as chair of the Fusarium Wilt Working Group of the CGIAR's International Network for the Improvement of Banana and Plantain.

Ploetz is a world authority on tropical fruit diseases, on which he has written more than 300 publications. He edited two books, Fusarium Wilt of Banana and Compendium of Tropical Fruit Diseases, for APS PRESS and another for CAB International, Diseases of Tropical Fruit Crops, which is now a standard reference. He is currently writing a two-volume book for SpringerVerlag, Tropical Plant Pathology, which will be a current and comprehensive update of this important topic. He has been interviewed often on tropical disease problems, most recently during scares on the extinction of banana and the increasing and 
serious impact of diseases on cacao (chocolate) production (e.g., the Discovery channel, NPR Canada, and Ira Flatow's Science Friday). Ploetz received the University of Florida Research Foundation Professor Award in 2004.

Ploetz has served APS in diverse capacities. He has filled several roles in the Office of International Programs (OIP). As director (2004-2007), he initiated translations of lessons on the Education Center to different languages, actively sought participation by young professionals in OIP, and developed the Sister Society Initiative (SSI). The SSI has morphed into an ad hoc committee that evaluates current and future international societal, publishing, and assistance activities of APS. As chair of this committee, he was part of a recent APS delegation to Beijing that started a relationship with the Chinese Society of Plant Pathology. This developing relationship will serve as a model for future interactions with other societies. Ploetz has written frequent articles in Phytopathology News to inform members of international activities, most recently the OIP News and Views column. And as past chair of OIP's awards committee, he prepared the nominations for 16 individuals for APS awards; 11 of these were successful (seven Fellow and four International Service Awards).

Ploetz was on the APS PRESS Editorial Board for 8 years (1995-2002), from 2000 to 2002 as editor-in-chief and from 1995 to 2000 as a senior editor (in 1999-2000 he also served as the new liaison with the Office of Electronic Communications). He served on APS Council, the APS Financial Advisory Committee, and the APS Publications Board while editor-in-chief and chaired the Publications Board in 2002. He was an associate editor for Phytopathology and served on the Classics Committee and the Tropical Plant Pathology Committee and served as a member and chair of the Soil Microbiology \& Root Disease Committee. He is a former president of the Florida Phytopathological Society and founding editor of the newsletter of that society and is a former vice president and managing editor for refereed papers for the Florida State Horticultural Society.

\section{Noel T. Keen Award for Research in Molecular Plant Pathology}

This award recognizes APS members who have made outstanding contributions and demonstrated sustained excellence and leadership in research that significantly advances the understanding of molecular aspects of host-pathogen interactions, plant pathogens or plant-associated microbes, or molecular biology of disease development or defense mechanism.

\section{Brett M. Tyler}

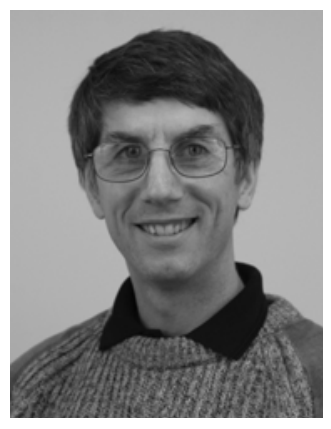

Brett M. Tyler was born on August 29, 1955, in Vancouver, Canada. He received his B.Sc. (Hons) degree from Monash University, Australia, in 1977 and his Ph.D. degree in medical biology from the University of Melbourne, Australia, in 1981. He was a postdoctoral fellow from 1982 to 1984 at the University of Georgia and a research fellow at the Australian National University, Australia, from 1984 to 1988. He was appointed an associate professor in the Department of Plant Pathology at the University of California, Davis in 1988 and promoted to full professor in 1994. In 2002, he accepted a position at the Virginia Polytechnic Institute and State University as professor in the Virginia Bioinformatics Institute and in the Department of Plant Pathology, Physiology and Weed Science.

Tyler's research in plant pathology has focused on understanding the molecular mechanisms by which oomycete pathogens, such as Phytophthora, overcome plants' defense mechanisms. Tyler's first major contribution to the molecular genetics of oomycetes was his development of a DNA transformation system for Phytophthora infestans and P. sojae in collaboration with Howard Judelson and Richard Michelmore, thus opening the possibility of direct functional manipulation of oomycete genes. In 1994, in collaboration with Helga Forster and Michael Coffey, he used molecular markers to demonstrate sexual reproduction in the clonally reproducing species $P$. sojae. The recognition that outcrossing had caused the development of many new races of $P$. sojae led his team to develop the first Mendelian genetic system for this pathogen, opening the way for genetic identification and map-based cloning of many genes. In 1995, he began building genomics resources for $P$. sojae and, in 1997, founded the community-based Phytophthora Genome Initiative, with Bruno Sobral, to build EST and genome sequencing programs for Phytophthora species. This initiative was highly successful in obtaining private and federal funding, resulting in large EST collections for $P$. sojae and $P$. infestans and in oomycete genomics databases at the National Center for Genome Resources and the Virginia Bioinformatics Institute. In 2002, he and his collaborators won funding for the sequencing of $P$. sojae and $P$. ramorum. Building on these first two genome sequences, Tyler was awarded funding for sequencing the genome of the Arabidopsis downy mildew pathogen Hyaloperonospora parasitica in 2004, enabling the exciting fusion of oomycete genomics with Arabidopsis genetic resources. Other members of the Phytophthora Genome Initiative have leveraged the $P$. sojae and $P$. ramorum sequences to obtain funding for genome sequencing of $P$. infestans, $P$. capsici, and Pythium ultimum. Most recently, Tyler has received funding to complete the $P$. sojae genome sequence and integrate all the oomycete genome sequences into a single resource, thus providing the community with an invaluable resource for future research. Tyler also has created an Affymetrix GeneChip microarray for $P$. sojae to facilitate functional genomics studies by the community. He also is leading the multiinstitutional PAMGO project to develop gene ontology terms for describing gene functions in a broad diversity of plant-associated microbes.

Tyler's research into the biology of oomycetes has made major contributions to understanding the molecular basis of recognition between Phytophthora species and their hosts. His team characterized elicitin proteins secreted by many Phytophthora species and demonstrated their importance in regulating the 
interaction of Phytophthora species with Nicotiana species. In collaboration with Paul Morris, his team characterized the recognition by $P$. sojae hyphae and swimming zoospores of isoflavone signals released by soybean roots. In 2004, his team described the cloning of the first avirulence gene from an oomycete, Avrlb, showing that it encoded a highly polymorphic protein and predicting that the protein should have the ability to enter plant cells. Searching the $P$. sojae and $P$. ramorum genomes with the $A v r l b$ sequence, he and his collaborators discovered a very large family of effector proteins with a conserved $\mathrm{N}$-terminal motif called RXLR-dEER. The family is present in all sequenced oomycete genomes and includes 12 cloned avirulence genes. The RXLR-dEER motif was widely predicted to carry the effector protein into plant cells and Tyler and others have recently proven this experimentally. The identification of the RXLR-dEER family of effectors has created a rush of excitement to understand the functions of these effectors. In addition to his research on effectors, Tyler currently has active soybean and $P$. sojae functional genomics research projects focused on understanding the complex network of genetic interactions between the host and pathogen that underlies the disease interaction. Understanding the interaction from a many-genes-to-many-genes perspective will lay the groundwork for long-term and durable technologies for improving plant resistance against oomycete pathogens.
A hallmark of Tyler's visionary leadership has been his determination that the oomycete molecular genetics community should have a strong spirit of collaboration, that tools and knowledge should be rapidly shared prior to publication, and that the careers of new entrants to the community should be actively fostered. Building on the Phytophthora Genome Initiative, he obtained a community-building Research Collaboration Network grant for the Phytophthora molecular genetics community from 2002 to 2007 and a follow-up grant for the oomycete genomics community from 2007 to 2012 . Tyler has actively fostered the career of many new oomycete molecular genetics researchers; the majority of his research grants have been in partnership with junior colleagues. Several of his postdoctoral fellows have become major contributors to the field, including APS Ruth Allen Award winner Howard Judelson and APS Syngenta Award winner Sophien Kamoun. The community that began with less than five research groups in 1986 now has more than 80 oomycete molecular genetics and genomics researchers worldwide. The genomic tools and resources that Tyler and his collaborators developed and the culture of cooperation that he has fostered within the community have transformed the field of oomycete molecular genetics over the last 20 years. This field, which was once regarded as a "career destroyer," is now vibrant and contributing cutting-edge knowledge to the field of molecular plant-microbe interactions at large.

\section{Ruth Allen Award}

This award recognizes individuals who have made an outstanding, innovative contribution to research that has changed or has the potential to change the direction in any field of plant pathology.

\section{Peter D. Nagy}

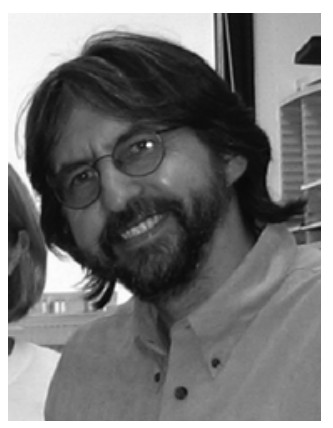

Peter D. Nagy was born in Csorna, Hungary. He received his M.Sc. degree in plant protection (a 5-year undergraduate/graduate program) from the University of Keszthely in 1985, and in 1990, he received his Ph.D. degree, summa cum laude, in plant virology and plant pathology from the same institution. His Ph.D. work was conducted in the Plant Protection Institute in the Hungarian Academy of Sciences. In 1983, he won first prize at the International Student Conference in Plovdiv, Bulgaria, as well as the Most Outstanding Young Undergraduate Student Award from Hungary's Ministry of Agriculture, and from 1985 to 1988, he was a recipient of a Hungarian Academy of Sciences doctoral fellowship. Following his Ph.D. degree, Nagy was awarded a United Nations' International Development Organization postdoctoral fellowship to support his virology studies in Italy. Thereafter, Nagy undertook additional postdoctoral research at Northern Illinois University with Jozef Bujarski and at the University of Massachusetts with Anne Simon. In 1999, Nagy joined the University of Kentucky's Plant Pathology Department as an assistant professor. Nagy was given accelerated promotion to associate professor, with tenure (2003), and professor (2007). He was recognized with a Science and Engineering Award from the governor of Kentucky (2002), with the College of Agriculture's Principal Grantsmanship (2006) and
Research (2007) Awards, and as a university research professor (2007-2008).

Nagy's foremost scientific achievements, which have made him a world authority on RNA virus replication and recombination, can be summarized as follows. (i) Introduction of a systems biology approach to identify host factors influential in the replication of Tomato bushy stunt virus (TBSV) via utilizing the "model" host, yeast. (ii) Identification of the first host factors suppressing or enhancing TBSV recombination based on genome-wide screens in yeast. To date, 32 such host genes have been detected through screening $95 \%$ of yeast genes. (iii) Employment of a highly tractable, yeast-based replication system for TBSV, thus accessing the power of yeast genetics. (iv) Analysis of the assembly requirements for the TBSV replicase using a proteomics approach, revealing two viral proteins and four host proteins that are integral parts of the tombusvirus replicase complex. (v) Development of cell-free systems employing purified recombinant TBSV replicase from yeast and plants that led to the discovery of novel, cisacting, silencer and enhancer regulatory RNA elements in the TBSV genome. (vi) Demonstration of the recruitment of host factors to the subcellular site of tombusvirus replication. (vii) Formulation of in vitro assays for viral RNA recombination, allowing the dissection of the molecular mechanisms involved.

Nagy's accomplishments, so briefly outlined here, reflect exhaustive studies of high intellectual challenge. It is of particular significance that Nagy's studies have made the plant virus TBSV, which infects vegetables and fruit trees, one of the best characterized among all viruses with regard to RNA replication and recombination, as well as one of the most thoroughly understood with respect to molecular perspectives of host interactions. 
Nagy's pioneering investigations have opened up new ways for virologists studying human and animal diseases. For example, his insights gained with a plant virus are opening new vistas, generally, about how more-virulent viral strains evolve. Clearly, Nagy has made outstanding, innovative research contributions that have changed - and will continue to change - the direction of research in plant pathology and beyond.

Nagy's publication record is truly exceptional, and while certainly representing a major influence in plant science and plant virology, his research has implications well beyond the boundaries of these disciplines.
In 2000, Nagy joined the editorial board of Virology, a considerable honor especially considering that he was an assistant professor at the time. In addition to his editorial duties for Virology, and recently for Journal of Virology, Nagy serves as an ad hoc reviewer for numerous leading journals. He has sat on multiple NSF, NIH, and USDA National Research Initiative grant review panels. In 2004, the EPA called on him to serve on a scientific advisory panel for his expertise regarding viral-transgenic plants. From 2002 to 2005, Nagy was a member of the American Society for Virology's Planning Committee, a role of considerable importance to that society.

\section{William Boright Hewitt and Maybelle Ellen Ball Hewitt Award}

This award recognizes a scientist within five years of their Ph.D. degree who has made an outstanding, innovative contribution directed toward the control of plant disease.

\section{Pierce A. Paul}

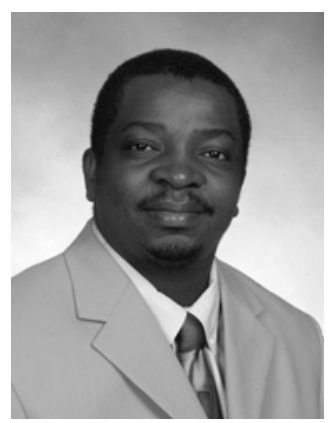

Pierce A. Paul was born and raised in Guyana, South America. He earned his undergraduate degree in agronomy and his M.S. degree in plant pathology from the Federal University of Viçosa, Brazil, under the guidance of Francisco Xavier Ribeiro do Vale. In 2003, he graduated with a Ph.D. degree in plant pathology, with a minor in statistics, from Iowa State University, under the guidance of Gary Munkvold. In the summer of 2003, he joined Pat Lipps and Larry Madden in the Department of Plant Pathology at The Ohio State University (OSU) as a postdoctoral researcher. He became a research scientist in 2005, and in August 2006, Paul joined the faculty of OSU, with research and extension responsibilities for small grain and maize diseases. In a short 5 years, Paul has made major research advances on two major diseases of field crops, gray leaf spot of maize (Cercospora zeae-maydis) and Fusarium head blight of wheat (FHB or scab, caused by Fusarium graminearum [Gibberella zeae]). As part of his Ph.D. research, he developed prediction models for gray leaf spot based on data collected through detailed statistical surveys of commercial fields over several years, coupled with state-of-the-art data-analytical methods. He used artificial-neural-network, logistic regression and classification-and-regression-tree approaches to develop risk models, which can be used before planting (to make hybrid selection and evaluate the risk of growing certain hybrids or to decide even if it is worth growing maize in a given year and location) or during the season (to make fungicide application decisions). With the increased acreage of maize in the Midwest and the higher unit prices for grain, these risk models have now taken on greater significance.

Since moving to OSU, Paul has made several key contributions to our understanding of the epidemiology and control of FHB, perhaps the most economically important disease of any crop in the United States over the last two decades. Because of the economic impact of FHB, several scientists from around the United States, under the auspices of the U.S. Wheat and Barley Scab Initiative, have been studying disease epidemics (and toxin production) in relation to the environment and crop characteristics and to disease (and toxin) management. Paul has established himself as a key member of the epidemiology and management teams, using his expertise in statistics to assist in the coordination of multistate projects, organization of data, and quantitative synthesis of research findings. One highly significant contribution is his use of meta-analysis to combine results from more than 150 studies (collected over a decade) to characterize the relationship between disease intensity measurements and resulting deoxynivalenol (DON) levels in harvested grain. Numerous instances of high variability and uncertainty in this relationship have been reported, as well as conflicting results between studies, with no general consensus on whether DON could even be predicted from field symptoms of FHB. Through the meta-analysis, Paul and colleague Madden showed that a significant positive and linear relationship between "disease index" and DON exists; the strength of the relationship (precision) was greater for spring wheat compared with winter wheat; the mean DON level was higher for spring than for winter wheat at a given level of disease; DON contamination may exist even when visible disease intensity is 0; and a very high variability in the relationship between FHB index and DON occurs. Based partly on these results, a new series of coordinated studies have been initiated in multiple states to elucidate the causes of the variation.

Paul has been at the forefront of the application of metaanalysis and other statistical methods for addressing problems in plant pathology. He and collaborators have used meta-analysis to characterize the effects of triazole fungicides on FHB and DON, based on data from more than 100 studies from the last decade. Results clearly demonstrated the significant degree of control that can be obtained; the poorer control of DON compared with disease symptoms; the better control for spring than for winter wheat; and also the high variation in degree of control. Spores of the FHB pathogen had previously been shown to be wind disseminated within and between wheat canopies. However, together with former OSU postdoc S. El-Allaf, Paul showed that spores also are routinely splashed dispersed within canopies during rain episodes and that rain splash is sufficient to transport spores to the wheat spikes where infection can occur. A significant relationship between rain intensity and spore transport was documented. Based on these results, both wind and rain-splash dispersal mechanisms must be considered in determining the risk of the 
disease. In additional research based on data collected in more than 8 years as part of the national scab initiative, he showed that there is a significant relationship between spore density on wheat spikes and profiles of atmospheric moisture, temperature, and rainfall over 8-day periods, although the variability is high. This result depended on the unique use of polynomial distributed lag regression analysis coupled with linear mixed model analysis. In other research, Paul, together with OSU colleagues, have characterized the relationship between field severity ("disease index") and incidence of FHB using a novel nonlinear model and have shown how the precision of the predicted index is related to the precision of the sampled incidence. This work is useful to improve understanding of population development and spread of FHB in wheat at different scales and to develop sampling schemes based on relatively easy-to-measure incidence, with a subsequent prediction of field severity using the model.

Paul is a very productive scientist, with 15 peer-reviewed journal articles in the last 4 years. He is very active nationally, currently serving as chair of the APS Epidemiology Committee and the USDA Technical Committee/project NCERA184, "Management of Small Grain Diseases." He has been an invited speaker at two national conferences in the last 3 years. He also plays a critical role in OSU's wheat breeding programs, screening for resistance to multiple diseases.

\section{Syngenta Award}

This award is given by Syngenta to an APS member for an outstanding contribution to teaching, research, or extension in plant pathology.

\section{Seogchan Kang}

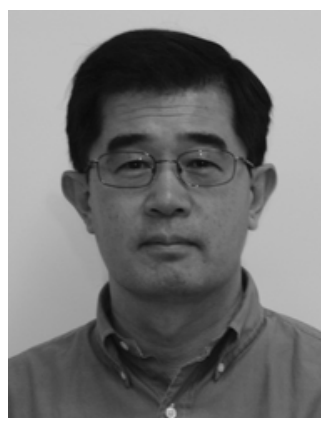

Seogchan Kang was born in Korea and obtained his B.S. and M.S. degrees in chemistry in 1983 and 1985, respectively, from Seoul National University. He completed his Ph.D. degree in physiological chemistry under the supervision of Robert L. Metzenberg in 1991 from the University of Wisconsin. Kang was a visiting scientist at DuPont until 1994 and had postdoctoral appointments at Purdue University and the University of New Mexico between 1994 and 1997. In 1997, he joined the faculty of the Department of Plant Pathology at the Pennsylvania State University, where he is currently an associate professor. His research focuses on genetic mechanisms underlying race variation in the rice blast system, molecular and cellular mechanisms underpinning $\mathrm{Fu}-$ sarium wilt, and development of informatics platforms supporting pathogen genomics, forensics, and systematics. He has served APS as a member or chair of three APS committees and as a reviewer for APS journals.

Kang has developed a multifaceted research program, and his contributions to plant pathology have come from four main areas. His seminal contribution has been his leadership in the establishment of a novel informatics platform to support and integrate community research on Phytophthora. Pathogen cultures often form the primary link that connects discoveries of the present with established knowledge of the past and support pathogen forensics. However, available resources for the archiving and use of pathogen culture collections have been grossly inadequate, resulting in the loss of important historic isolates and also causing fragmentations in community research. Kang and collaborators have created an integrative informatics platform, named the Phytophthora Database (www.phytophthoradb.org), that supports Phytophthora identification and monitoring by archiving genotypic and phenotypic data associated with previously characterized isolates in an easily searchable format. In the long run, the database will support the integration and utilization of data from diverse areas of research on Phytophthora, ranging from genomics, phylogenetics, and population biology to epidemiology. The impact of this work will expand beyond the better understanding and management of Phytophthora, since this informatics platform can easily be adopted to support new global networks for monitoring other pathogen groups.

Kang's second major contribution to plant pathology has come from his studies of the genetic mechanisms underpinning race variation in the rice blast system. Although gene-for-gene-mediated resistance is highly effective once triggered, such resistance frequently loses its effectiveness in the field due to the emergence of new races. Kang has been addressing the question of how new races arise at multiple levels, ranging from individual avirulence genes to field populations. His work with Magnaporthe oryzae has increased our understanding of the roles of various genetic elements in causing genetic instability of its avirulence genes and of the distribution, evolution, and variation of avirulence genes in natural populations.

An area of research that Kang and collaborators have pioneered that has begun to pay rich dividends is a new experimental model system for the study of soilborne fungal diseases using Arabidopsis thaliana and Fusarium oxysporum. Because much of our current knowledge in the molecular basis of plant-pathogen interactions has been derived from studies based on foliar fungal pathogens, our understanding of soilborne fungal diseases lags considerably behind that of foliar diseases. His work on the $A$. thaliana-F. oxysporum system has yielded many new insights into the molecular and cellular mechanisms underpinning root pathogenesis from both the host and pathogen sides. In addition to the identification of genes important for root pathogenesis, fourdimensional imaging of interaction sites via confocal/multiphoton microscopy revealed many novel features underpinning their interactions.

Lastly, Kang has offered his knowledge and achievements to many in plant pathology through the development of research tools and collaborations. Two most notable tools that have been distributed to many laboratories are Agrobacterium-mediated transformation and gene manipulation tools and fluorescent protein-based reporters and physiological sensors. He also has collaborated with many pathologists who have field-oriented research programs nationally and internationally (China, Greece, India, Korea, and Spain). One notable example is Kang's contribution to the Pennsylvania Department of Agriculture (PDA). Since 2003, he has helped PDA establish and run a molecular diagnostic laboratory so that PDA can quickly respond to several emerging pathogen threats. Considering the increasing impor- 
tance of integrative approaches in solving plant disease problems, Kang's collaborative work presents an exemplary model for such approaches.

Kang has given 18 invited lectures in national and international symposia on topics of his current research focus. In addition, he has presented 33 invited seminars at U.S. and international universities. He has published 46 peer-reviewed journal articles, four book chapters, and two conference proceedings. He has served as an associate editor for two journals, has been a reviewer for more than 20 journals, and has served on four grant review panels. 